
Society

\title{
Development of scenarios for land cover, population density, impervious cover, and conservation in New Hampshire, 2010-2100
}

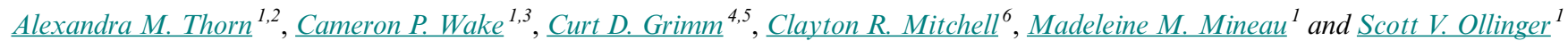

\begin{abstract}
Future changes in ecosystem services will depend heavily on changes in land cover and land use, which, in turn, are shaped by human activities. Given the challenges of predicting long-term changes in human behaviors and activities, scenarios provide a framework for simulating the long-term consequences of land-cover change on ecosystem function. As input for process-based models of terrestrial and aquatic ecosystem function, we developed scenarios for land cover, population density, and impervious cover for the state of New Hampshire for 2020-2100. Key drivers of change were identified through information gathered from six sources: historical trends, existing plans relating to New Hampshire's land-cover future, surveys, existing population scenarios, key informant interviews with diverse stakeholders, and input from subject-matter experts. Scenarios were developed in parallel with information gathering, with details added iteratively as new questions emerged. The final scenarios span a continuum from spatially dispersed development with a low value placed on ecosystem services (Backyard Amenities) to concentrated development with a high value placed on ecosystem services (the Community Amenities family). The Community family includes two population scenarios (Large Community and Small Community), to be combined with two scenarios for land cover (Protection of Wildlands and Promotion of Local Food), producing combinations that bring the total number of scenarios to six. Between Backyard Amenities and Community Amenities is a scenario based on linear extrapolations of current trends (Linear Trends). Custom models were used to simulate decadal change in land cover, population density, and impervious cover. We present raster maps and proportion of impervious cover for HUC10 watersheds under each scenario and discuss the trade-offs of our translation and modeling approach within the context of contemporary scenario projects.
\end{abstract}

Key Words: conservation; ecosystem services; forests; impervious cover; land cover change; land use zoning; population density; scenarios;

\section{INTRODUCTION}

Alongside climate change, changes in land cover and land use have been highlighted as central drivers of change in ecosystems and the services they provide (Vitousek et al. 1997, Millennium Ecosystem Assessment 2005). These changes are largely driven by human actions, and the inherent complexity of human behaviors presents a major challenge for quantitatively predicting future change (Liu et al. 2007, Polasky et al. 2011). Scenarios provide a framework for projecting future changes when uncertainty is high: scenarios do not predict the future, but rather present collections of alternative storylines for plausible futures, which can provide insight on the range of possible outcomes (Schwartz 1991). Here, we present the development of a suite of high-resolution land-cover change scenarios for the state of New Hampshire that serve as input for process-based models, part of a U.S. National Science Foundation-funded project to evaluate temporal variability of future ecosystem services in the state (Mavrommati et al. 2016, Samal et al. 2017; Borsuk et al., unpublished manuscript).

New Hampshire has experienced large-scale land-cover change in the past, and there is a high degree of uncertainty about future land cover in the state with consequences for ecosystem services. Since the 17th century, New Hampshire has changed from primarily forest, to $\sim 50 \%$ farmland in the mid-19th century, back to primarily forest (Foster et al. 2010). Since 1987, New Hampshire has lost forest area to development (Drummond and Loveland 2010, Foster et al. 2010, Levesque 2010, Thompson et al. 2013, Jeon et al. 2014), especially in the southeast (Johnson 2012, Sundquist 2012). Although population growth has slowed since 2000 (Johnson 2012), several projections suggest that development in the southeast will continue to expand over the subsequent several decades (Stein et al. 2009, USEPA 2009, Bierwagen et al. 2010, Stein et al. 2010, Sundquist 2012), with major implications for ecosystem services in the region. For example, three watersheds in southern New Hampshire have been ranked in the top five watersheds nationally in terms of projected degradation of water quality due to increased housing density on existing private forestland (Stein et al. 2009), and the same watersheds are classified in the 90th percentile nationally in terms of threats to forest species at risk from housing development (Stein et al. 2010). However, the state also has a long and robust history of grassroots conservation. Thirty percent $\left(7300 \mathrm{~km}^{2}\right)$ of the state's land area is publicly or privately conserved (NH GRANIT 2016). This includes $3000 \mathrm{~km}^{2}$ in the White Mountain National Forest, which was established in 1918 to mitigate hydrological damage to streams from intensive logging (Shands 1992, Conroy and Ober 2001). Overall, the competing land uses of development, forestry, conservation, and agriculture produce a high degree of uncertainty about the future of New Hampshire's landscapes, and for land-cover scenarios to best inform future changes in the state, these competing uses must be addressed.

Our research builds on an extensive and growing body of literature on the use of scenarios for a variety of functions in environmental forecasting and planning (Peterson et al. 2003, Swart et al. 2004, Alcamo et al. 2006, Carpenter et al. 2006). Methods for scenario development and modeling are highly dependent on the specific objectives of a scenario effort (Mallampalli et al.2016) and should generally meet the following goals: specific needs of the target

${ }^{1}$ Earth Systems Research Center, Institute for the Study of Earth, Oceans, and Space, University of New Hampshire, ${ }^{2}$ Gerald J. and Dorothy R. Friedman School for Nutrition Science and Policy, Tufts University, ${ }^{3}$ Department of Earth Sciences, University of New Hampshire, ${ }^{4} \mathrm{Carsey} \mathrm{School}$ of Public Policy, University of New Hampshire, ${ }^{5}$ Department of Anthropology, University of New Hampshire, ${ }^{6}$ Department of Natural Resources and the Environment, University of New Hampshire 
audience (relevance), transparent and justified methods (credibility), perception of fairness (legitimacy), and provoking new thinking about uncertainty (creativity; Alcamo et al. 2006). These goals are often addressed through engagement of stakeholders, including decision makers, experts, and groups affected by scenario outcomes (Mallampalli et al. 2016). Approaches to translating available information into useful scenarios include innovative methods to involve stakeholders directly in model construction (e.g., Schmitt Olabisi et al. 2010) or to incorporate stakeholder knowledge into mathematical models (e.g., Bayesian networks; Meyer et al. 2014b), but traditional methods such as interviews and surveys remain major approaches to stakeholder engagement (Mallampalli et al. 2016). For example, key informant interviews are central to scenario development protocols recommended by the Natural Capital Project run by The Nature Conservancy and the World Wildlife Fund (Rosenthal et al. 2015). These traditional methods, alongside literature review, are well suited for collaboration with experts and can be used in combination with diverse modeling methods (Mallampalli et al. 2016). Translation of qualitative results into quantitative models can be iterative, as in the Storyline and Simulation approach in which stakeholders are asked to provide feedback on scenarios (Alcamo 2008), or, when resources are more limited or stakeholders are unable to commit to multiple workshops, a more streamlined approach can be used, drawing on published literature (Pfeifer et al. 2012).

Scenario developers must consider several components contributing to future change (e.g., in land cover): the driving forces that shape the relevant system processes; the predetermined elements that can be assumed to follow a predictable trajectory; and critical uncertainties, which are unknown, poorly understood, or can change in unpredictable ways (Schwartz 1991). However, driving forces are not always well understood, and critical uncertainties can emerge from unexpected changes to factors regarded as predetermined elements (Schwartz 1991). It is also possible for more than one set of driving forces to produce the same outcome (Moss et al. 2010). When thorough knowledge of a system is required for credibility or when modeling is used to develop a more sophisticated understanding of the system, it can be critical to explicitly model social, economic, and physical drivers (Nakicenovic et al. 2000, Wear 2011, Radeloff et al. 2012) and quantify parameter uncertainty (e.g., Alcamo et al. 2011, Verburg et al. 2013). However, excessive complexity can delay research because scenarios must be revised continually based on improved knowledge. Spatially explicit modeling of land-cover change is particularly complex, and the models are highly sensitive to underlying assumptions about driving forces; in fact, variability among models due to differing assumptions can be larger than differences among scenarios (Sohl et al. 2016). Models generally fail to predict the spatial distribution of land change at high resolution (Pontius et al. 2008), and projections are constrained by the interval of training data sets, typically 20 to 30 years (van Vliet et al. 2016), with uncertainty increasing for longer term projections (Pontius and Spencer 2005).

Our objective was to develop plausible, spatially explicit scenarios for land-cover change, population density, and impervious cover in New Hampshire from 2010 to 2100 as part of the larger NH EPSCoR Ecosystems and Society project (Gardner et al., unpublished manuscript). The scenarios served as critical input for linked terrestrial and aquatic ecosystem process models used to project changes in future environmental functions and the resulting changes in ecosystem services (Samal et al. 2017). The scenarios also served as a key source of information regarding alternate futures as part of novel deliberative multicriteria evalutions described by Mavrommati et al. (2016). Based on a combination of literature review, key informant interviews, and collaboration with subject matter experts, we produced six distinct scenarios for the future of land cover, conservation, population density, and impervious cover, and used custom models to generate decadal rasters for each of these attributes.

\section{METHODS}

\section{Study site}

New Hampshire covers $24,214 \mathrm{~km}^{2}$ in northern New England, between $42^{\circ} 42^{\prime}$ and $45^{\circ} 18^{\prime} \mathrm{N}$ and between $70^{\circ} 36^{\prime}$ and $72^{\circ} 33^{\prime} \mathrm{W}$. The state is currently $75 \%$ forest, $5.5 \%$ developed, and $4.5 \%$ in farmland (NH GRANIT 2016; Fig. 1A). Some forest is managed for timber, especially in the northern region of the state; some is conserved for wildlife, recreation, or to protect ecosystem services; and some (particularly land held by small landowners) is subjected to a wide variety of land management practices. Most land area in New Hampshire is rural or low density (Fig. 1B), and most of the state's population of 1.3 million lives in small towns. The three largest cities, Manchester (110,000 residents), Nashua (86,000 residents), and Concord (43,000 residents), are all located in a densely populated, central, Interstate 93 corridor in the southern portion of the state along the Merrimack River (U.S. Census Bureau 2013). The state is characterized by high rates of education (ranked seventh nationally) and family income (ranked eighth nationally), but the educated and high-income population is primarily located in the southeast (Johnson 2012). The northern portion of the state is lower income, with a rural economy dominated by manufacturing and timber industries (Johnson 2012) that are currently in decline. Farmland in the state is primarily located in the southeast and along the Connecticut River, which defines the western border of the state.

Fig. 1. New Hampshire land cover in 2011 (A) and population density in 2010 (B). Sources: (A) Rubin and Justice (unpublished data), enhancing NOAA (2014); (B) U.S. Census Bureau (2012).

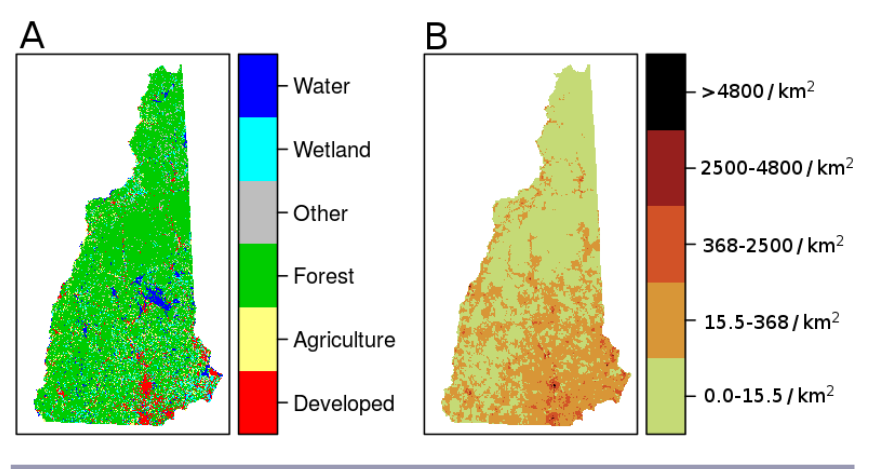

\section{Approach}

From the outset, we wanted to develop a suite of credible, legitimate, and relevant scenarios that were divergent in land cover, population density, and impervious cover, with contrasting 
consequences for ecosystem function and services. Our initial ideas were informed by previous land-cover scenarios developed for the Lamprey River watershed in southeastern New Hampshire (Scholz 2011) and Massachusetts (Thompson et al. 2013, 2014), as well as contrasting development patterns across southern New Hampshire, i.e., concentrated in the coastal city of Portsmouth vs. distributed in the many small communities along the Interstate 93 corridor adjacent to the Massachusetts border within a 72-97$\mathrm{km}$ driving distance of Boston, Massachusetts.

To develop the scenarios, we sought information on possible landcover futures from six different sources: historical trends, existing plans relating to New Hampshire's land-cover future, surveys, existing population scenarios, key informant interviews, and subject matter experts. Scenarios were developed in parallel with information gathering, in a relatively unstructured fashion, by iteratively incorporating new details and pursuing new information sources as questions emerged from internal conversations, interviews with key informants, or input from subject matter experts.

\section{Historical trends}

New Hampshire's demographic growth outpaced the rest of the northeastern United States by a significant margin through the last three decades of the 20th century and into the first few years in the 21st century (Johnson 2012). Population growth since 2007 has been slower but still greater than in other states in New England. This demographic growth has not been even across the state, however. Most of the population increase has been concentrated in the southeastern and south-central portions of the state. Corresponding with population growth, the same time intervals have seen a rapid expansion in developed land area, with most development as suburban and exurban housing (Sundquist 2012, Mockrin et al. 2013). Farmland area decreased throughout the state from the late 19th century to near the end of the 20th century, with some farms abandoned and reverting to forest and others converted to development (USDA-NASS 2012). Rates of conservation have accelerated in recent decades, primarily because of the actions of land trusts and other organizations (Meyer et al. 2014a), including broad interest in protecting the agricultural land base and expanding local food production (Donahue et al. 2014, American Farmland Trust 2016; Northeast Sustainable Agriculture Working Group http://nesawg.org). Nevertheless, most protected land is in the northern half of the state and at high elevations, where development pressure is lowest (Levesque 2010).

Existing plans and visions for New Hampshire's land-cover future We relied on three reports regarding the future of New Hampshire's and New England's land use and land cover to inform our land-cover scenarios. The 2009 New Hampshire Climate Action Plan (New Hampshire Climate Change Policy Task Force 2009, Wake et al. 2011) represents a consensus plan developed through a process that engaged $>125$ stakeholders and 29 task force members (representing a broad range of sectors and interests, including the New Hampshire House and Senate, New Hampshire state agencies, municipal government, business and industry, environmental nonprofit organizations, the forestry sector, academia, and public utilities). One of ten overarching strategies was to protect New Hampshire's natural resources to maintain the amount of carbon sequestered by avoiding net forestland conversion and protecting existing agriculture land. In 2010, Harvard Forest published Wildlands and Woodlands: A Vision for the New England Landscape (Foster et al. 2010). The vision calls for a 50 -year effort to conserve $70 \%$ of New England as forest permanently free from development, and efforts to support this vision continue. Finally, a common focus across recent New England state food system plans or strategies is in expanding food production and the agricultural land base (Vermont Sustainable Jobs Fund 2013, Metropolitan Area Planning Council 2015, New Hampshire Food Alliance 2015, Maine Food Strategy 2016). A New England Food Vision builds on the desires for expanded agricultural production in the region and describes a future in which New England produces at least half of the region's food by 2060 via an expansion of agricultural lands from 0.8 million to 2.4-2.8 million ha (Donahue et al. 2014). Food Solutions New England's (http://www.foodsolutionsne.org) commitment to furthering this vision has been codified in a series of annual New England food system summits beginning in 2011 and by establishing a vibrant regional network.

Surveys

In 2013, New Hampshire's nine Regional Planning Commissions sponsored a survey of 2935 New Hampshire adult residents as part of a larger project (A Granite State Future, funded by U.S. Housing and Urban Development) to engage New Hampshire citizens in a public dialogue regarding the future of their communities and state (Keirns et al. 2013). Additional input was gathered during key informant interviews with leaders of the $A$ Granite State Future project and during a separate meeting with Commissioners from the nine Regional Planning Commissions (Table 1). More than two-thirds $(70 \%)$ of respondents favor keeping future development in existing developed areas, $96 \%$ view water-quality protection as a high priority, and $76 \%$ place high priority on protecting aquatic habitats. Nearly three-quarters (74\%) think that policy makers should invest more money for maintaining roads, highways, and bridges, whereas only $40 \%$ supported more funds for improving the availability of public transportation.

\section{Existing population scenarios}

Population projections for New Hampshire have been generated both locally (New Hampshire Regional Planning Councils 2014) and nationally (e.g., Bierwagen et al. 2010). To represent diverging futures, we adapted the New Hampshire Office of Energy and Planning projection (2014) as a low population scenario and the A2 population scenario developed by the Integrated Climate and Land Use Scenarios used by the third National Climate Assessment for a high population scenario (Bierwagen et al. 2010). We also consulted census data for the state since 1990 as the basis for a simple linear extrapolation of current rates of population growth (U.S. Census Bureau 1993, 2013).

Key informant interviews

Key informants from 12 organizations representing five sectors related to land use and land cover (environmental nonprofits, business and industry, timber interests, public sector agencies, and academics and natural resource management consultants; Table 1) were identified based on our knowledge of the state and recommendations from individuals in leadership positions and were invited to participate in facilitated group interviews. Ten of the twelve organizations who participated in the interviews 
Table 1. List of organizations that were interviewed, with sector and number of people.

\begin{tabular}{|c|c|c|c|}
\hline Organization & Sector $^{\dagger}$ & Region represented & $\begin{array}{l}\text { Number of } \\
\text { people }\end{array}$ \\
\hline Neil and Louise Tillotson Trust Advisory Committee & Mixed & Northern & 10 \\
\hline New Hampshire Energy and Climate Collaborative & Mixed & Statewide & 12 \\
\hline New Hampshire Water and Watershed Conference & A \& C & Statewide & 30 \\
\hline New Hampshire EPSCoR Statewide Committee & Mixed & Statewide & 12 \\
\hline Commissioners, Regional Planning Commission & Gov. & Statewide & 9 \\
\hline $\begin{array}{l}\text { New Hampshire State Agencies (Department of Environmental Services, Department of } \\
\text { Health and Human Services, and Department of Resources and Economic Development) }\end{array}$ & Gov. & Statewide & 20 \\
\hline Granite State Futures & Gov. & Statewide & 20 \\
\hline Society for the Protection of New Hampshire Forests, Board of Directors & Env. & Statewide & 9 \\
\hline Society for the Protection of New Hampshire Forests, Staff & Env. & Statewide & 20 \\
\hline The Nature Conservancy (New Hampshire) and The Northern Forest Center & Env. & Statewide & 10 \\
\hline Innovative Natural Resource Solutions & Timber. & Statewide & 3 \\
\hline New Hampshire Home Builders Association & B \& I & Southern & 3 \\
\hline
\end{tabular}

${ }^{\dagger}$ Sectors represented include: academics and natural resource management consultants (A \& C), public sector agencies (Gov.), environmental nonprofits (Env.), timberland interests (Timber.), and business and industry (B \& I). We also interviewed mixed stakeholder groups.

represent statewide interests, and $>150$ key informants participated in these interviews (Table 1). During interviews, informants were asked two questions: (1) describe a picture of what you would like New Hampshire to look like in the future, two to four decades or more from now; and (2) describe a picture of what you expect New Hampshire to look like in the future, two to four decades or more from now. Details of our methodology are provided in Appendix 1. A majority of those interviewed favored a shift toward more compact residential development through some combination of local zoning ordinances, regulation favoring "smart growth" zoning (Addison et al. 2013), and market responses to increased demand for smaller houses and high costs of construction far from existing roads, sewers, and other infrastructure. Participants diverged on whether high or low population growth was desirable, with most public sector and industry representatives regarding higher population growth as desirable, whereas some members of environmental nonprofits expressed anxiety about the likelihood of land clearing to accommodate a growing population. A few stakeholders advocated for increased food production in the state, whereas others (representing timber and environmental interests) regarded expansion of agricultural land as a threat to natural resources. There were some stakeholders across sectors who expressed a desire for better management of forest, soil, and water to protect ecosystem services, and environmental nonprofit stakeholders in particular hoped for continued strategic land conservation.

When prompted to describe the future they expected, most stakeholders described a regulatory and zoning environment similar to their perceptions of the present day or with reduced environmental protections. The main source of differences was in the anticipated rate of population growth. Some stakeholders expected rapid population growth, continuing trends from the late 20 th century, which, combined with contemporary zoning, would result in most of the state filling with residential subdivisions. Others, particularly government stakeholders, expected low growth and increased demand for infrastructure to support an aging population. Still others imagined futures between these two extremes.

\section{Subject matter experts}

Throughout the process, we engaged subject matter experts on a range of topics. The members of the NH EPSCoR Ecosystem and Society project numbered $>60$ individuals from academic institutions across the state. They provided input via responses to our questions similar to those posed during key informant interviews as well as during monthly team meetings and biannual all-hands meetings. Key issues relating to forest management and existing and potential future conserved land were discussed in detail with members from the New Hampshire chapter of The Nature Conservancy and the Society for the Protection of New Hampshire Forests. We engaged Brian Donahue to help us interpret the New England Food Vision projections for future agricultural lands across New Hampshire. Demographer Ken Johnson advised us on the use of the Office of Energy and Planning population projections, which extend to the year 2040, and we subsequently obtained extrapolations to 2100 from Bob Scardamalia of RLS Demographics, the creator of the Office of Energy and Planning projection. In addition, one of the authors (CM), who originally connected with the project as a participant in key informant interviews, joined the team to provide detailed data on existing residential and commercial zoning in all 221 towns and 13 cities in New Hampshire.

\section{Translation}

Based on the diverse themes and information derived from these six sources (Table 2), we developed a suite of qualitative landcover scenarios (narratives) that were subsequently translated into quantitative land cover, population density, and impervious cover, essentially applying the story and simulation (SAS) approach (Mallampalli et al. 2016). The major driving forces that emerged from this process were population growth, zoning, conservation, and the role of agriculture in the state. Our translation methodology was iterative but relatively simple, relying on the authors' progressive synthesis of available information.

Based on the information we collected, we realized that it was crucial to capture a range of patterns of population distribution, with an upper limit on compact development defined by the restriction of new growth to redevelopment of previously developed land area (New Hampshire Climate Change Policy 
Table 2. Possible futures for New Hampshire that emerged from the six information sources we reviewed. Futures are organized by theme and by the two questions that were posed during key informant interviews interviews: (1) describe a picture of what you would like New Hampshire to look like in the future, two to four decades or more from now; and (2) describe a picture of what you expect New Hampshire to look like in the future. Supporting information, other than interviews, that was used to translate each idea into scenarios included: historical trends, plans and visions, surveys, population projections, and subject-matter experts.

\begin{tabular}{|c|c|c|c|c|c|c|}
\hline \multirow[b]{2}{*}{ Theme } & \multirow[b]{2}{*}{ Imagined future } & \multicolumn{5}{|c|}{ Information source $^{\dagger}$} \\
\hline & & $\begin{array}{l}\text { Historical } \\
\text { trends }\end{array}$ & $\begin{array}{l}\text { Plans, } \\
\text { visions }\end{array}$ & Surveys & $\begin{array}{l}\text { Population } \\
\text { projections }\end{array}$ & Experts \\
\hline \multicolumn{7}{|c|}{ What stakeholders would like New Hampshire to look like: } \\
\hline $\begin{array}{l}\text { Patterns of } \\
\text { development }\end{array}$ & $\begin{array}{l}\text { Cluster development combines smaller more affordable homes with } \\
\text { some backyard amenities while increasing access to public land and } \\
\text { decreasing ecological impact }\end{array}$ & & 1 & & & 2 \\
\hline $\begin{array}{l}\text { Patterns of } \\
\text { development }\end{array}$ & $\begin{array}{l}\text { Urban infill with mixed-use "smart growth" allows growth and } \\
\text { affordable housing while preserving all undeveloped landscapes and } \\
\text { associated services }\end{array}$ & & 1 & 3 & & \\
\hline $\begin{array}{l}\text { Population and } \\
\text { demography }\end{array}$ & New businesses attract young families & & 4 & 3 & 5 & \\
\hline Conservation & $\begin{array}{l}\text { Strategic conservation of corridors and other areas with high value for } \\
\text { ecosystem services or biodiversity }\end{array}$ & 6 & 7 & 3 & & 8 \\
\hline Forestry & Allowed to grow (limited harvest or long harvest cycle) & & 9 & & & \\
\hline Forestry & Traditional forestry (short harvest cycle, natural succession) & 10 & & & & 11 \\
\hline Agriculture & Continues to be minor part of landscape & $12,13,14$ & & & & \\
\hline Agriculture & Agricultural land area expands & & 15 & & & 16 \\
\hline \multicolumn{7}{|c|}{ What stakeholders expect New Hampshire to look like: } \\
\hline $\begin{array}{l}\text { Patterns of } \\
\text { development }\end{array}$ & $\begin{array}{l}\text { Continued traditional subdivisions result in rapid development of } \\
\text { remaining rural areas, shifting northward along major corridors }\end{array}$ & $17,18,19$ & & & & \\
\hline $\begin{array}{l}\text { Population and } \\
\text { demography }\end{array}$ & $\begin{array}{l}\text { Continuation of demographic shift toward aging population results in } \\
\text { increased demand for rural amenities and political engagement but } \\
\text { slower economic growth }\end{array}$ & 20 & & & 21 & 22,23 \\
\hline $\begin{array}{l}\text { Population and } \\
\text { demography }\end{array}$ & $\begin{array}{l}\text { Large influx of climate refugees stimulate economic growth but drive } \\
\text { continued subdivisions while impacting cultural norms of heavy water } \\
\text { use and devaluing the rural character of the state }\end{array}$ & & & & 5 & \\
\hline Conservation & Conservation continues similar to current or at more moderate pace & 6 & & & & 24 \\
\hline Conservation & $\begin{array}{l}\text { Conservation slows or halts and conservation easements are rolled } \\
\text { back }\end{array}$ & & & & & \\
\hline Forestry & Liquidation harvest and residential development & $17,18,19$ & & & & \\
\hline \multicolumn{7}{|c|}{$\begin{array}{l}\text { 'Sources and supporting information: 1, New Hampshire Climate Change Policy Task Force (2009); 2, coauthor Clay Mitchell; 3, Keirns et al. (2013); } \\
\text { 4, Gittell and Orcutt (2012); 5, A2 scenario (Bierwagen et al. 2010); 6, Meyer et al. (2014a); 7, Foster et al. (2010); 8, Representatives from The Nature } \\
\text { Conservancy and Society for Protection of New Hampshire Forests; 9, USDA Forest Service (2005); 10, USDA Forest Service (2005); 11, Eric } \\
\text { Kingsley; 12, NOAA C-CAP (NOAA 2014); 13, Rubin and Justice (unpublished data); 14, USDA-NASS (2012); 15, Donahue et al. (2014); 16, Brian } \\
\text { Donahue; 17, Drummond and Loveland (2010); 18, Mockrin et al. (2012); 19, Sundquist (2012); 20, Johnson (2012); 21, New Hampshire Office of } \\
\text { Energy and Planning (2015); 22, Ken Johnson; 23, Bob Scardamalia; 24, Representatives from The Nature Conservancy and Society for Protection of } \\
\text { New Hampshire Forests. }\end{array}$} \\
\hline
\end{tabular}

Task Force 2009). However, we were less clear on how the opposite extreme of dispersed population should be defined and distributed. Key informant interviews confirmed the importance of population distribution and growth as drivers of $\mathrm{New}$ Hampshire land cover and provided more specificity: in a highpopulation future, anticipated development was described as progressing northward from the southeast along major transportation corridors, whereas in the middle of the state, growth would be concentrated in a select few municipalities (Plymouth, Hanover, and Lebanon). In a low-population future, the location of growth would be defined by the county-based New Hampshire Regional Planning Councils (2014) projections.

Our original vision for the modeling process was to use land-cover change models derived from regression trees (De'ath and
Fabricius 2000) and decision trees and based on 1996-2011 landcover change data from the National Oceanic and Atmospheric Administration Coastal Change Analysis Program (NOAA CCAP; NOAA 2014), emulating a scenario effort for neighboring Massachusetts (Thompson et al. 2011, 2016). Regression trees provide the advantage of being intuitive to interpret and modify and have been shown to perform with similar realism to more sophisticated models for long-term projections (Tayyebi et al. 2014). However, this approach presented some challenges when the driver of land development was local change in population. Models for the low-density development scenario were therefore structurally modified to first simulate allocation of population among municipalities using a model derived from county-level population projections but designed to be consistent with a northward progression along transportation corridors. This 
custom model incorporated detailed information on residential lot sizes zoned for each municipality, and eventually we settled on a cost-distance weighted gravity model (see details in Appendix 2). The original regression tree models also tended, in some cases, to produce artificial and unrealistically sharp boundaries between converted and unchanged lands, and after both internal discussion among the authors and informal external conversation with stakeholders and scholars in the broader EPSCoR team, we decided to avoid these artifacts by adjusting the scale at which regression trees were computed (e.g., subregions within New Hampshire instead of for the whole state) and using careful selection of input variables that would be commensurate with the scale of simulation models (e.g., avoiding distance variables that operate at large scales when simulating land-cover change within a municipality).

Information gathered during key informant interviews suggested that the future of land conservation would play an important role in determining the effects of development on ecosystem services, a perception supported by the history of land conservation in the state. However, it was not clear what quantity or distribution of conservation would be considered necessary to protect these services. Thus, we engaged subject-matter experts at The Nature Conservancy and the Society for the Protection of New Hampshire Forests, who had previously identified high-priority areas for conservation. GIS experts from each organization shared their maps of conservation plans and helped us determine the priority threshold that would be most relevant for a highconservation future. At the other end of the spectrum, we internally debated whether a low-conservation future would have slow conservation, no conservation, or perhaps even a loss of conserved land relative to the present day. For this, we relied on local planning expertise and research (author CM), which suggested a natural political shift toward cluster zoning with land conservation as communities are built out, and this observation was incorporated into our final models. We also discovered that a linear extrapolation of conservation trends from the past two decades, which we had planned to use as an intermediate scenario between the two extremes, would in fact result in a larger area of conserved land by 2100 than was considered desirable by our conservation stakeholders. We believed this outcome was an unrealistic consequence of the unusually high rate of conservation from 1990 to the present (Meyer et al. 2014a). In this case, we decided that ending the extrapolated conservation in 2060 would give a more realistic result while providing similar simplicity to the general assumptions of a linear model.

Projecting future change in agricultural land area posed a particular challenge in the development of scenarios for land cover. Total land area and changes in land cover for this category were relatively small, limiting power for statistical analyses. In addition, the user and producer accuracy of Landsat-based landcover data are particularly low for the pasture/hay land category (Wickham et al. 2010), which represents $75 \%$ of cleared farmland in the state (USDA-NASS 2012). Our colleagues at NH GRANIT assisted us by providing an enhanced version of the NOAA CCAP rasters (Rubin and Justice, unpublished data). We were previously familiar with $A$ New England Food Vision (Donahue et al. 2014), which presents two scenarios for agricultural expansion to increase food security in the region. Given the mix of perspectives provided during the key informant interviews, we decided to include two different compact development scenarios, one assuming dramatic agricultural expansion based on Donahue et al. (2014), and another with much more modest agricultural expansion, continuing recent trends. We consulted with Brian Donahue to determine what land area would be appropriate for New Hampshire based on A New England Food Vision, and he provided specific agricultural land areas for the year 2060. He also advised that we use the more modest of the two scenarios in $A$ New England Food Vision, which represents a normative combination of increased food production alongside protection of forests. To keep this scenario simple, we assumed linear expansion in agricultural land area between the present day and the 2060 agricultural land provided in A New England Food Vision.

The final products of the translation process were custom landcover change models developed for each scenario (see Appendix 2), which produced decadal rasters of land cover and population density. Maps of impervious cover were derived from population density maps based on a regression model relating contemporary impervious cover to population density. To summarize the change in impervious cover at a watershed level, the proportion of impervious cover was calculated within HUC10 watershed boundaries (USDA-NRCS et al. 2015). We used a simple threshold model to classify watersheds as degraded (> $30 \%$ impervious), impacted ( $>10 \%$ impervious), or not impacted $(<$ 10\% impervious cover; Arnold and Gibbons 1996).

\section{THE SCENARIOS}

The six scenarios we developed fall on a continuum from dispersed development with a low value placed on shared ecosystem services to concentrated development with a high value placed on shared ecosystem services (Fig. 2A). The "Backyard Amenities" scenario (Backyard) is characterized by dispersed development with little regulation or effort to preserve ecosystem services combined with rapid population growth. The "Community Amenities" family of scenarios (Community) is characterized by concentrated development and a strong focus on the preservation of existing forest and agricultural lands. The Community family contains four scenarios, each informed by Foster et al. (2010). These differ along the axes of population growth ("Small Community" vs. "Large Community") and degree of agricultural expansion ("Protection of Wildlands" [Wildlands] vs. "Promotion of Local Food" [Food]; Fig. 2B), giving four scenarios within the family: Small Community-Wildlands, Large Community-Wildlands, Small Community-Food, and Large Community-Food). For all scenarios in this family (and to be consistent with the recommendations of the New Hampshire Climate Change Policy Task Force [2009]), all development occurs as redevelopment within existing developed areas. Between the Backyard scenario and the Community family is the "Linear Trends" scenario (Linear). To enhance the usefulness of these scenarios for social scientists and planners, each scenario is accompanied by general descriptions of associated economic, governmental, and cultural change (Appendix 3).

For the Backyard scenario, development rates were based on population projections, a database of the mean area zoned for future residential lots in each municipality, and historical trends in zoning changes in response to development pressure (C. Mitchell et al., unpublished manuscript). As each municipality is 
Fig. 2. Schematics of land cover scenarios. The three scenario families can be placed along a continuum from dispersed population with low value placed on shared ecosystem services to concentrated population with high value placed on shared ecosystem services (A), and the Community family is subdivided based on population growth and conservation priorities (B), giving a total of six scenarios: Backyard, Linear, Small Community + Wildlands, Small Community + Food, Large Community + Wildlands, and Large Community + Food.

A

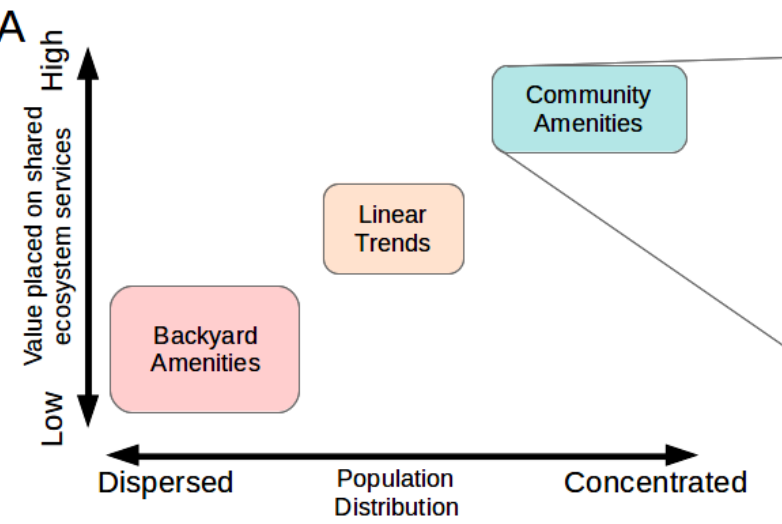

B

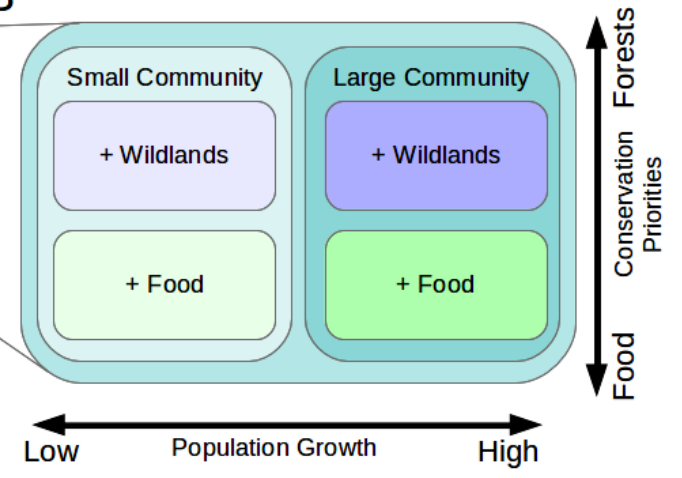

built out to $50 \%$ and then $62.5 \%$, land area per lot is reduced to reflect a political shift toward increasingly compact cluster zoning. The population density of newly developed land increases based on lot size and average households of 2.5 individuals (New Hampshire Office of Energy and Planning 2015), and impervious cover is updated based on population density. For the Community family, developed land area does not increase, so the projected increase in population is allocated to developed land with existing population (assumed to be residential areas), and impervious cover is correspondingly increased to reflect the necessary redevelopment to accommodate increased densities. In addition, where population density decreases, impervious cover is permitted to decline based on reduced residential requirements. The Food scenarios assume a linear expansion of agricultural land area to meet the target of $3640 \mathrm{~km}^{2}$ by the year 2060 . Because this vision is designed to be compatible with forest protection, we keep agricultural land area constant after 2060. The Linear scenario extrapolates recent trends in development for each of four regions in the state: the southeast, southwest, central, and north (see Appendix 2).

Rasters for the year 2100 of the four land-cover scenarios (Fig. 3) and four population-density scenarios (Fig. 4) reveal a collection of highly distinct futures for the southeastern and central portions of the state, with relatively minor differences in the north. Impervious cover increases in southeastern and central watersheds for all population scenarios except Small Community (Fig. 5A). This change is particularly dramatic for the Backyard scenario; by 2100 , the number of watersheds in the impacted category (impervious cover $>10 \%$; Arnold and Gibbons 1996) quadrupled relative to the present day (Fig. 5B). Only $750 \mathrm{~km}^{2}$ of new land is conserved for Backyard compared with $4000 \mathrm{~km}^{2}$ for Linear and $4700 \mathrm{~km}^{2}$ for the Community family (Fig. 6). The spatial distribution of land conservation is fragmented and haphazard in Linear and targeted and contiguous for Community.

\section{DISCUSSION}

The scenarios presented here reflect four main driving forces in New Hampshire: population growth, zoning, conservation, and the role of agriculture in the state. The result is one scenario with rapid dispersed development (Backyard), a suite of compact growth scenarios (Community), and one intermediate scenario (Linear). In the Backyard scenario, southeastern and central New Hampshire are almost entirely built out by 2100 , a higher end estimate of what the state could look like if recent trends continue (see shorter term projections from New Hampshire Fish and Game 2005, Stein et al. 2009, 2010). Impervious cover increases, bringing 15 new HUC10 watersheds (USDA-NRCS et al. 2015) in southern New Hampshire into the "impacted" category by 2100 (Arnold and Gibbons 1996). In contrast, the future presented by the Community family of scenarios maintains all of the undeveloped land of the present day, aligned with the goals set out by the New Hampshire Climate Change Policy Task Force (2009) and reflecting information gathered in the 2013 survey (Keirns et al. 2013) and key informant interviews. The Wildlands and Food scenarios within the Community family present two contrasting futures for rural land use within the state: one similar to the present day; and one in which the landscape is transformed to support a large portion of the food demand within the region, resulting in a dramatic expansion in farmland in areas suitable for agriculture (i.e., central New Hampshire, coastal plain, and along the Connecticut River valley), a future that in some ways resembles land cover in the mid- to late 1800s. The Small Community scenarios represent little change in population or impervious cover, whereas in the Large Community scenarios, many southeastern and central population centers experience growing high-density populations while rural spaces are protected. The Small Community scenarios are similar to the Large Community scenarios but without any significant population growth, requiring little change to municipal infrastructure from the present day. 
Fig. 3. Scenarios for land cover in 2100. Maps are shown for the four land-cover scenarios: Backyard, Linear, Wildlands, and Food.

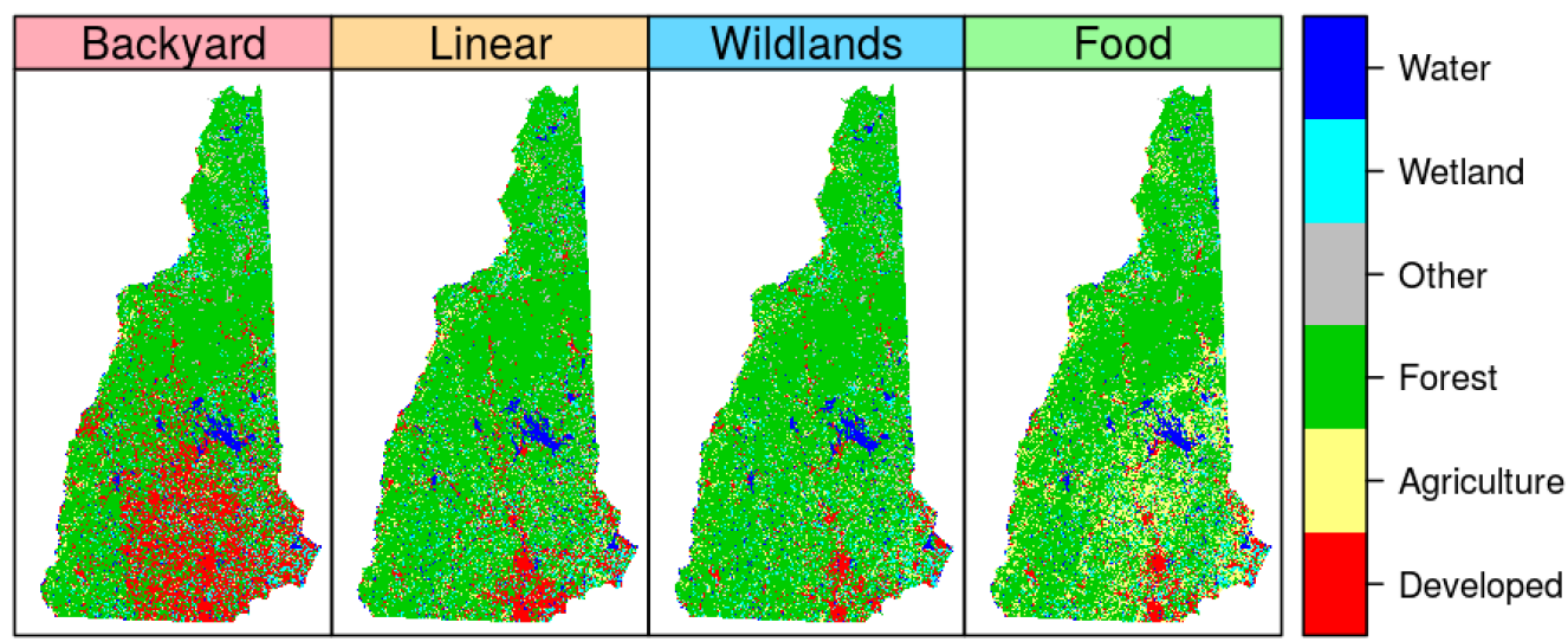

Fig. 4. Spatial distribution of population density classes in 2100 for each of the four scenarios for population distribution: Backyard, Linear, Small Community, and Large Community. Below the maps for the three scenarios, time series are shown for the number of people living at each density class and the land area with each population density class.

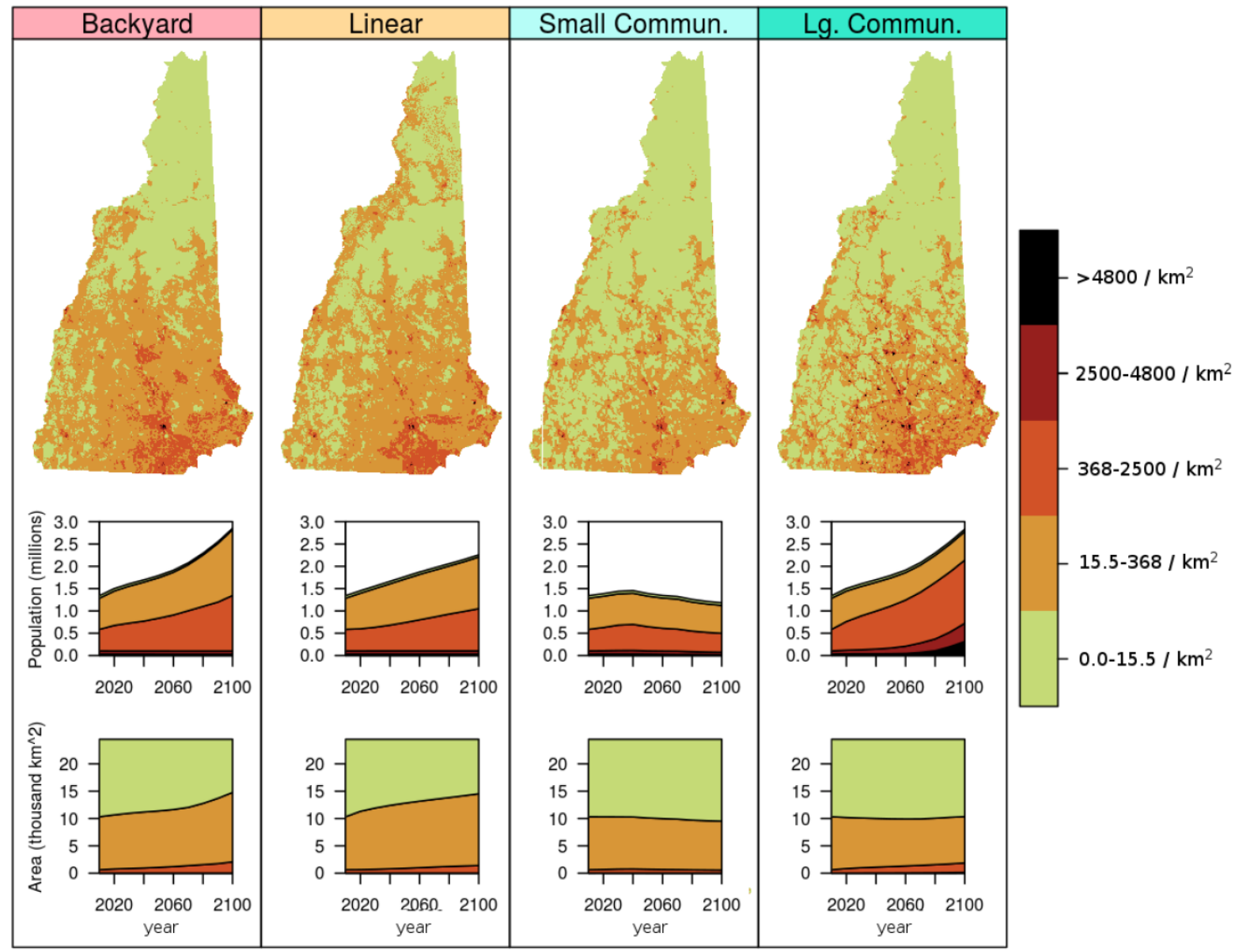


Fig. 5. Proportion (\%) impervious cover by HUC10 watershed for 2100 for each scenario (A) and changes in number of impacted watersheds ( $>10 \%$ impervious cover) contained in or overlapping the state $(\mathrm{B})$.

A

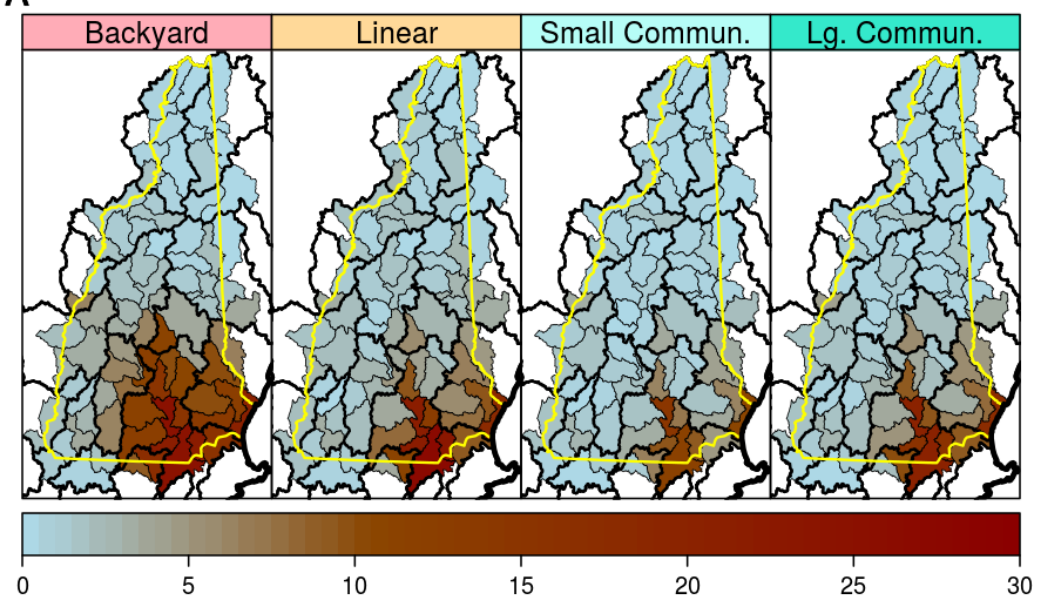

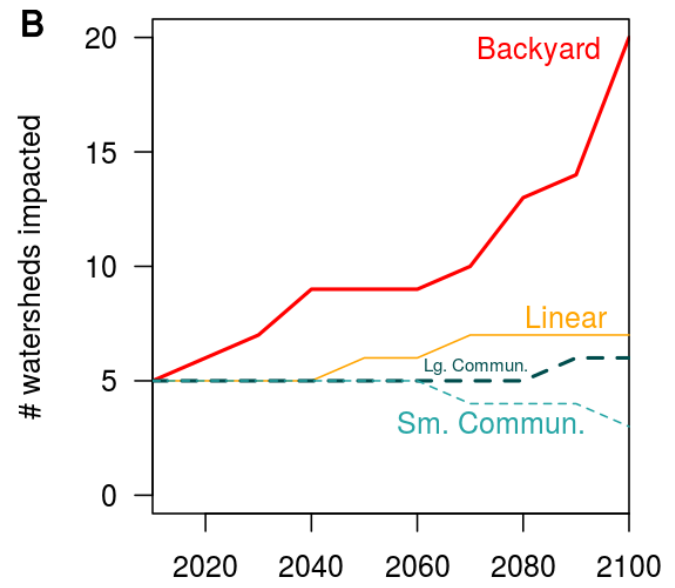

year
Fig. 6. Scenarios for land conservation in 2100 for three scenario families: Backyard, Linear, and Community. Light green $=$ land conserved in the present day, dark green $=$ newly conserved land under each scenario.

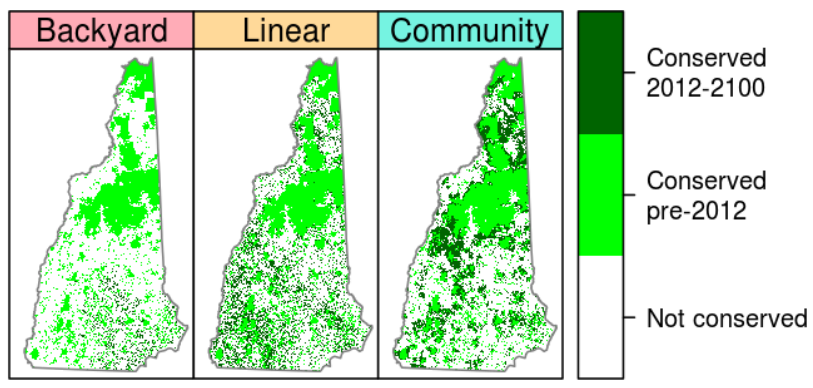

Our modeling priority was to produce maps that would resonate as plausible to New Hampshire stakeholders. To achieve this, we used an iterative SAS approach to develop and calibrate custom models based on diverse local sources of information (Table 2). Key knowledge incorporated into the scenarios included details of contemporary zoning (C. Mitchell et al., unpublished manuscript), existing conservation plans (The Nature Conservancy New Hampshire Chapter, unpublished data; Society for the Protection of New Hampshire Forests, unpublished data), the New Hampshire Climate Action Plan (New Hampshire Climate Change Policy Task Force 2009), and a normative vision for the future agricultural land area in the state (Donahue et al. 2014). For two scenarios, we also used a population projection from the state's Office of Energy and Planning (New Hampshire Regional Planning Councils 2014). Because that projection represents a low population future and some stakeholders expected a high population future, we also used national projections from the U.S. Environmental Protection Agency's Integrated Climate and Land-Use Scenarios (EPA ICLUS) report (Bierwagen et al. 2010). The final result was a suite of six distinctly local scenarios relevant in different ways to a diversity of local stakeholders.

We worked to limit the number of scenarios based on the longstanding recommendation that scenario development should be restricted to three or four scenarios (Schwartz 1991, Peterson et al. 2003). However, the diversity of interests among stakeholders prompted us to expand the Community scenario into a family of scenarios to better match the interests of different stakeholders. Nevertheless, we recommend that users of these scenarios identify two to four scenarios most relevant for their purposes. For example, researchers and planners interested in the relative importance of population and population density might focus on the Backyard, Large Community-Wildlands, and Small Community-Wildlands scenarios, whereas food systems professionals might focus on the capacity of New Hampshire to feed a growing population in the Backyard, Large CommunityFood, and Large Community-Wildlands scenarios.

An important methodological decision in our approach was to bound the scope of our models to the specific driving variables identified by stakeholders, rather than to attempt to develop an integrated model of all aspects of the system. Thus, the model for Backyard explicitly includes zoning and population, but we did not model the economic mechanisms that would drive the spatial distribution of population or development. Likewise, for the Food scenarios, we modeled a simple trajectory consistent with Donahue et al. (2014) and, because our scenarios focused on New Hampshire and not the region as a whole, we did not assume that regional demand would necessarily differ between the two population variants. We combined statistical models, extrapolation, expert knowledge, normative vision, and zoning data to simulate each scenario but did not attempt to predict scenario differences with a single model. Our approach differs, for example, from econometric models, which assess the potential 
consequences of specific policy decisions on land-cover change based on current knowledge of markets (e.g., Radeloff et al. 2012), and Bayesian belief networks, which rely on the ability of expert stakeholders to characterize the interrelationships among driving variables (McCloskey et al. 2011, Meyer et al. 2014b, Carpenter et al. 2015). Although the resulting models are less suitable for mechanistic analysis of the interdependence of the factors driving governance and land-use choices than other approaches, we believe that our models satisfied our primary goal of developing divergent scenarios consistent with stakeholder intuitions. The scenarios also represent particular divergence with regard to population distribution as compared to other scenario sets (e.g., Bierwagen et al. 2010).

In part to maintain the simplicity of our models and in part as a result of the limited resources available for a small-scale scenario effort, we borrowed in places from the approach used in the development of the representative concentration pathways, which are the basis for current scenarios in climate modeling, and which describe trajectories of changing emissions without modeling the mechanisms that produce each pathway (Moss et al. 2008, 2010). Notably, we used published projections for our high (Bierwagen et al. 2010) and low (New Hampshire Regional Planning Councils 2014) population scenarios, but we consider the magnitude of change to be more important than the underlying demographic variables such as age structure, fertility, or migration. For instance, although the EPA ICLUS A2 population projection assumes high fertility rates and high domestic migration, our Backyard and Large Community scenarios could be equally useful for highpopulation futures produced by other mechanisms. Such growth might result, for example, if domestic populations shift in response to changing climate. New England is expected to receive slightly increased precipitation under most climate change scenarios (Hayhoe et al. 2007, Melillo et al. 2014), whereas it is generally accepted that the recent droughts in the U.S. southwest will continue (Walsh et al. 2014). Migration of even a small percentage of U.S. residents from drier areas to wetter areas over the coming decades could produce a dramatic increase in the state's population.

\section{Lessons learned}

Our experience in scenario development exemplifies the challenges of small-scale scenario development with limited resources. Our interdisciplinary team included a mix of natural scientists and social scientists but did not include researchers with preexisting expertise in scenario development or with specialized knowledge of statistical and engagement tools that might have aided in systematic translation of stakeholder perspectives into internally consistent models (Mallampalli et al. 2016). For example, use of fuzzy cognitive maps or Bayesian networks could have produced more immediate translation from stakeholder perspectives into quantitative scenarios (Mallampalli et al. 2016). Our project would likely have been enhanced by the inclusion of additional academic disciplines on the team such as a demographer who could provide more customized population projections or an economist with knowledge of land valuation, supply chains, and distribution networks. In addition, although we endeavored to engage stakeholders from a balanced collection of sectors in the state, our reliance on snowball sampling could have introduced selection or gatekeeper bias (Bonevski et al. 2014), preventing us from hearing the perspectives of important groups not represented in our professional networks. For example, a clear area for improvement in the scenarios would have been more sophisticated modeling of the timing and spatial distribution of increased farmland area in the Food scenario, which might have been enhanced by more engagement of experts in food production or distribution or, alternatively, by the inclusion of an economist on the team.

The transparency of our process also would have been improved if we had used more systematic methods to collect data from key informant interviews, including recording, transcription, and quantitative analysis of responses. It is therefore not possible to delve further into the interviews to identify patterns among the data and the different informants, which could help to predict whether there might be identifiable triggers associated with the different futures. Finally, our timeline did not allow for iterative engagement of the stakeholders that we interviewed to invite them to critique our preliminary scenarios, as is recommended in the classic SAS approach (Alcamo et al. 2006). This method could have provided significant refinement of the details of the different population distributions and the accompanying economic, governmental-regulatory, and cultural change narratives.

Overall, our scenario development process strongly centered on the decisions and intuitions of the research team and assigned priority to the perspectives of stakeholders with close working relationships with the authors. While this can enhance collaboration between researchers and specific technical experts outside of academia (Pulver and VanDeveer 2009), a clear criticism of this approach is the bias it introduces, amplifying the voices of some stakeholders over others. On the flip side, the use of engagement methods that require minimal investment by stakeholders may have increased the breadth of perspectives included, and reliance on existing collaborative relationships may have enabled us to include more specific detail than might have been included if we insisted on a more statistical representation of stakeholders.

\section{Future directions}

In addition to the use of these scenarios in the ecosystem modeling efforts that combine land-cover scenarios with high and low emissions climate scenarios (Samal et al. 2017) and an investigation of the role of imagined futures in shaping the value placed on ecosystem services (Borsuk et al., unpublished manuscript), they are also informing conversations among municipal planners. Based on a 2016 stakeholder workshop, highresolution maps have been generated to inspire further discourse (http://ddc-landcover.sr.unh.edu/). Future research will build on these projects to further assess dynamic changes to ecosystem services in response to climate and land-cover change. An important area for refinement of the scenarios will be spatially explicit modeling of land use and land management, particularly for agriculture and managed forests.

Responses to this article can be read online at: http://www.ecologyandsociety.org/issues/responses. php/9733 


\section{Acknowledgments:}

We thank Barbara Wauchope for helping with key informant interviews, Fay Rubin and David Justice for developing the base maps of land cover and answering questions about NH GRANIT data sets, Joshua Plisinski for processing the elevation and slope maps, Robert Spoerl for conservation dates from the NH DRED database, Chris Wells and Will Abbot for providing the Society for the Protection of New Hampshire Forests conservation plans, Peter Steckler for providing The Nature Conservancy conservation plans, and Bob Scardamalia for extrapolating the New Hampshire Office of Energy and Planning population projection. We thank Jennifer Wilhelm and Brian Donahue for reviewing ideas for the agricultural expansion scenarios, David Lutz and Ross Jones for information on forest management in the White Mountain National Forest, and Shan Zuidema for ideas on modeling impervious cover. We thank Michele Dillon for friendly review and three anonymous reviewers who provided valuable critiques during the revision process. Finally, we thank our numerous stakeholders for their contributions to the development of our scenarios. This research was supported by a grant from the National Science Foundation (EPS-1101245).

\section{LITERATURE CITED}

Addison, C., S. Zhang, and B. Coomes. 2013. Smart growth and housing affordability: a review of regulatory mechanisms and planning practices. Journal of Planning Literature 28(3):215-257. http://dx.doi.org/10.1177/0885412212471563

Alcamo, J. 2008. The SAS approach: combining qualitative and quantitative knowledge in environmental scenarios. Pages 123-150 in J. Alcamo, editor. Environmental futures: the practice of environmental scenario analysis. Elsevier, Amsterdam, The Netherlands. http://dx.doi.org/10.1016/S1574-101X(08)00406-7

Alcamo, J., K. Kok, G. Busch, J. A. Priess, B. Eickhout, M. Rounsevell, D. S. Rothman, and M. Heistermann. 2006. Searching for the future of land: scenarios from the local to global scale. Pages 137-155 in E. F. Lambin and H. J. Geist, editors. Landuse and Land-cover change. Springer, Berlin, Germany. http://dx. doi.org/10.1007/3-540-32202-7_6

Alcamo, J., R. Schaldach, J. Koch, C. Kölking, D. Lapola, and J. Priess. 2011. Evaluation of an integrated land use change model including a scenario analysis of land use change for continental Africa. Environmental Modelling and Software 26(8):1017-1027. http://dx.doi.org/10.1016/j.envsoft.2011.03.002

American Farmland Trust. 2016. Mission and history. American Farmland Trust, Washington, D.C., USA. [online] URL: https:// www.farmland.org/mission-history

Arnold, C. L. Jr., and C. J. Gibbons. 1996. Impervious surface coverage: the emergence of a key environmental indicator. Journal of the American Planning Association 62(2):243-258. http://dx. doi.org/10.1080/01944369608975688

Bierwagen, B. G., D. M. Theobald, C. R. Pyke, A. Choate, P. Groth, J. V. Thomas, and P. Morefield. 2010. National housing and impervious surface scenarios for integrated climate impact assessments. Proceedings of the National Academy of Sciences 107 (49):20887-20892. http://dx.doi.org/10.1073/pnas.1002096107
Bonevski, B., M. Randell, C. Paul, K. Chapman, L. Twyman, J. Bryant, I. Brozek, and C. Hughes. 2014. Reaching the hard-toreach: a systematic review of strategies for improving health and medical research with socially disadvantaged groups. $B M C$ Medical Research Methodology 14:42. http://dx.doi. org/10.1186/1471-2288-14-42

Carpenter, S. R., E. M. Bennett, and G. D. Peterson. 2006. Scenarios for ecosystem services: an overview. Ecology and Society 11(1):29. http://dx.doi.org/10.5751/ES-01610-110129

Carpenter, S. R., E. G. Booth, S. Gillon, C. J. Kucharik, S. Loheide, A. S. Mase, M. Motew, J. Qiu, A. R. Rissman, J. Seifert, E. Soylu, M. Turner, and C. B. Wardropper. 2015. Plausible futures of a social-ecological system: Yahara watershed, Wisconsin, USA. Ecology and Society 20(2):10. http://dx.doi. org/10.5751/ES-07433-200210

Conroy, R. G., and R. Ober, editors. 2001. People and place: Society for the Protection of New Hampshire Forests: the first 100 years. Society for the Protection of New Hampshire Forests, Concord, New Hampshire, USA.

De'ath, G., and K. E. Fabricius. 2000. Classification and regression trees: a powerful yet simple technique for ecological data analysis. Ecology 81(11):3178-3192. http://dx.doi. org/10.1890/0012-9658(2000)081[3178:CARTAP]2.0.CO;2

Donahue, B., J. Burke, M. Anderson, A. Beal, T. Kelly, M. Lapping, H. Ramer, R. Libby, and L. Berlin. 2014. A New England food vision. Food Solutions New England, University of New Hampshire, Durham, New Hampshire, USA. [online] URL: http://www.foodsolutionsne.org/sites/default/files/LowResNEFV 0. pdf

Drummond, M. A., and T. R. Loveland. 2010. Land-use pressure and a transition to forest-cover loss in the eastern United States. BioScience 60(4):286-298. http://dx.doi.org/10.1525/bio.2010.60.4.7

Foster, D., B. M. Donahue, D. B. Kittredge, K. F. Lambert, M. L. Hunter, B. R. Hall, L. C. Irland, R. J. Lilieholm, D. A. Orwig, A. W. D'Amato, E. A. Colburn, J. R. Thompson, J. N. Levitt, A. M. Ellison, W. S. Keeton, J. D. Aber, C. V. Cogbill, C. T. Driscoll, T. J. Fahey, and C. M. Hart. 2010. Wildlands and woodlands: a vision for the New England landscape. Harvard University Press, Cambridge, Massachusetts, USA. [online] URL: http://www. wildlandsandwoodlands.org/sites/default/files/Wildlands $\% 20$ and $\%$ 20Woodlands $\% 20 \mathrm{New} \% 20$ England.pdf

Gittell, R., and J. Orcutt. 2012. Science and technology plan: shaping New Hampshire's economic future. University of New Hampshire, Durham, New Hampshire, USA. [online] URL: https://www.unh.edu/research/sites/www.unh.edu.research/files/docs/ NH_EPSCoR/NH_Science_Technology_Plan_2011.pdf

Hayhoe, K., C. P. Wake, T. G. Huntington, L. Luo, M. D. Schwartz, J. Sheffield, E. Wood, B. Anderson, J. Bradbury, A. DeGaetano, T. J. Troy, and D. Wolfe. 2007. Past and future changes in climate and hydrological indicators in the US Northeast. Climate Dynamics 28(4):381-407. http://dx.doi. org/10.1007/s00382-006-0187-8

Jeon, S. B., P. Olofsson, and C. E. Woodcock. 2014. Land use change in New England: a reversal of the forest transition. Journal of Land Use Science 9(1):105-130. http://dx.doi.org/10.1080/1747423X.2012.754962 
Johnson, K. M. 2012. New Hampshire demographic trends in the twenty-first century. Carsey School of Public Policy, University of New Hampshire, Durham, New Hampshire, USA. [online] URL: http://scholars.unh.edu/cgi/viewcontent.cgi?article=1163\&context= carsey

Keirns, T. A., Z. Azem, and A. E. Smith. 2013. NH Regional Planning Commissions: a Granite State future: 2013 statewide survey. Survey Center, University of New Hampshire, Durham, New Hampshire, USA. [online] URL: http://www.granitestatefuture. org/files/1413/8023/1024/RPC Statewide Report FINAL.pdf

Levesque, C. A. 2010. New Hampshire statewide forest resources assessment - 2010: important data and information about New Hampshire's forests. New Hampshire Department of Resources and Economic Development Division of Forests and Lands, Concord, New Hampshire, USA. [online] URL: http://www. nhdfl.org/library/pdf/Planning/ $/ \mathrm{NH}^{2}$ 20 Statewide $\% 20$ Assessment $\%$ 202010\%20update.pdf

Liu, J., T. Dietz, S. R. Carpenter, M. Alberti, C. Folke, E. Moran, A. N. Pell, P. Deadman, T. Kratz, J. Lubchenco, E. Ostrom, Z. Ouyang, W. Provencher, C. L. Redman, S. H. Schneider, and W. W. Taylor. 2007. Complexity of coupled human and natural systems. Science 317(5844):1513-1516. http://dx.doi.org/10.1126/ science. 1144004

Maine Food Strategy. 2016. The Maine food strategy framework: a tool for advancing Maine's food system. Maine Food Strategy, Maine, USA. [online] URL: http://mainefoodstrategy.org/wpcontent/uploads/2016/06/Maine-Food-Strategy-Framework final. pdf

Mallampalli, V. R., G. Mavrommati, J. Thompson, M. Duveneck, S. Meyer, A. Ligmann-Zielinska, C. Gottschalk Druschke, K. Hychka, M. A. Kenney, K. Kok, and M. E. Borsuk. 2016. Methods for translating narrative scenarios into quantitative assessments of land use change. Environmental Modelling and Software 82:7-20. http://dx.doi.org/10.1016/j.envsoft.2016.04.011

Mavrommati, G., M. E. Borsuk, and R. B. Howarth. 2016. A novel deliberative multicriteria evaluation approach to ecosystem service valuation. Ecology and Society 22(2):39. https://doi. org/10.5751/ES-09105-220239

McCloskey, J. T., R. J. Lilieholm, and C. Cronan. 2011. Using Bayesian belief networks to identify potential compatibilities and conflicts between development and landscape conservation. Landscape and Urban Planning 101(2):190-203. http://dx.doi. org/10.1016/j.landurbplan.2011.02.011

Melillo, J. M., T. C. Richmond, and G. W. Yohe, editors. 2014. Climate change impacts in the United States: the third National Climate Assessment. U.S. Government Printing Office, Washington, D.C., USA. http://dx.doi.org/10.7930/J0Z31WJ2

Metropolitan Area Planning Council, Franklin Regional Council of Governments, Pioneer Valley Planning Commission, and Massachusetts Workforce Alliance. 2015. Massachusetts local food action plan. Massachusetts Food System Collaborative, Massachusetts, USA. [online] URL: http://mafoodsystem.org/ plan/

Meyer, S. R., C. S. Cronan, R. J. Lilieholm, M. L. Johnson, and D. R. Foster. 2014a. Land conservation in northern New England: historic trends and alternative conservation futures. Biological Conservation 174:152-160. https://doi.org/10.1016/j.biocon.2014.03.016

Meyer, S. R., M. L. Johnson, R. J. Lilieholm, and C. S. Cronan. 2014b. Development of a stakeholder-driven spatial modeling framework for strategic landscape planning using Bayesian networks across two urban-rural gradients in Maine, USA. Ecological Modelling 291:42-57. https://doi.org/10.1016/j. ecolmodel.2014.06.023

Millennium Ecosystem Assessment. 2005. Ecosystems and human well-being: current state and trends. Island Press, Washington, D. C., USA. [online] URL: https://www.millenniumassessment.org/ en/Condition.html

Mockrin, M. H., S. I. Stewart, V. C. Radeloff, R. B. Hammer, and K. M. Johnson. 2013. Spatial and temporal residential density patterns from 1940 to 2000 in and around the northern forest of the northeastern United States. Population and Environment 34 (3):400-419. https://doi.org/10.1007/s11111-012-0165-5

Moss, R., M. Babiker, S. Brinkman, E. Calvo, T. Carter, J. Edmonds, I. Elgizouli, S. Emori, L. Erda, K. Hibbard, R. Jones, M. Kainuma, J. Kelleher, J.-F. Lamarque, M. Manning, B. Matthews, J. Meehl, L. Meyer, J. Mitchell, N. Nakicenovic, B. O’Neill, R. Pichs, K. Riahi, S. Rose, P. Runci, R. Stouffer, D. van Vuuren, J. Weyant, T. Wilbanks, J. P. van Ypersele, and M. Zurek. 2008. Towards new scenarios for analysis of emissions, climate change, impacts, and response strategies. Technical summary. Intergovernmental Panel on Climate Change, Geneva, Switzerland. [online] URL: https://www.ipcc.ch/pdf/supportingmaterial/expert-meeting-ts-scenarios.pdf

Moss, R. H., J. A. Edmonds, K. A. Hibbard, M. R. Manning, S. K. Rose, D. P. van Vuuren, T. R. Carter, S. Emori, M. Kainuma, T. Kram, G. A. Meehl, J. F. B. Mitchell, N. Nakicenovic, K. Riahi, S. J. Smith, R. J. Stouffer, A. M. Thomson, J. P. Weyant, and T. J. Wilbanks. 2010. The next generation of scenarios for climate change research and assessment. Nature 463(7282):747-756. http://dx.doi.org/10.1038/nature08823

Nakicenovic, N., J. Alcamo, G. Davis, B. de Vries, J. Fenhann, S. Gaffin, K. Gregory, A. Grübler, T. Y. Jung, T. Kram, E. L. La Rovere, L. Michaelis, S. Mori, T. Morita, W. Pepper, H. Pitcher, L. Price, K. Riahi, A. Roehrl, H.-H. Rogner, A. Sankovski, M. Schlesinger, P. Shukla, S. Smith, R. Swart, S. van Rooijen, N. Victor, and Z. Dadi. 2000. Special report on emissions scenarios. A special report of Working Group III of the Intergovernmental Panel on Climate Change. Cambridge University Press, Cambridge, UK. [online] URL: https://www.ipcc.ch/pdf/specialreports/emissions_scenarios.pdf

National Oceanic and Atmospheric Administration (NOAA). 2014. C-CAP New Hampshire 1996-2010-era land cover change. Coastal Change Analysis Program Regional Land Cover, NOAA Office for Coastal Management, Charleston, South Carolina, USA. [online] URL: https://www.coast.noaa.gov/ccapftp/\#/

New Hampshire Climate Change Policy Task Force. 2009. The New Hampshire climate action plan: a plan for New Hampshire's energy, environmental and economic development future. New Hampshire Department of Environmental Services, Concord, New Hampshire, USA. [online] URL: http://des.nh.gov/ organization/divisions/air/tsb/tps/climate/action_plan/ nh climate action plan.htm 
New Hampshire Fish and Game. 2005. New Hampshire Wildlife Action Plan. New Hampshire Fish and Game, Concord, New Hampshire, USA. [online] URL: http://www.wildlife.state.nh.us/ wildlife/wap.html

New Hampshire Food Alliance. 2015. Farm, fish, and food enterprise viability in New Hampshire. New Hampshire Food Alliance, Durham, New Hampshire, USA. [online] URL: http:// www.nhfoodalliance.com/sites/default/files/NHFA $\% 20 \mathrm{VI} \% 20$ RevisedFinal $\% 20$ Edit.pdf

New Hampshire Office of Energy and Planning. 2015. 2014 population estimates of New Hampshire cties and towns. New Hampshire Office of Energy and Planning, Concord, New Hampshire, USA. [online] URL: http://www.nh.gov/oep/datacenter/documents/population-estimates-2014.pdf

New Hampshire Regional Planning Councils. 2014. County population projections, 2013: by age and sex. RLS Demographics, Rensselaerville, New York, USA. [online] URL: http:// regionalplan.uvlsrpc.org/files/4613/8780/6428/Projections_FinalReport. pdf

NH GRANIT. 2016. New Hampshire's statewide GIS clearinghouse. University of New Hampshire, Durham, New Hampshire, USA. [online] URL: http://granit.unh.edu/

Peterson, G. D., G. S. Cumming, and S. R. Carpenter. 2003. Scenario planning: a tool for conservation in an uncertain world. Conservation Biology 17(2):358-366. http://dx.doi.org/10.1046/ j.1523-1739.2003.01491.x

Pfeifer, C., M. P. W. Sonneveld, and J. J. Stoorvogel. 2012. Farmers' contribution to landscape services in the Netherlands under different rural development scenarios. Journal of Environmental Management 111:96-105. http://dx.doi.org/10.1016/ j.jenvman.2012.06.019

Polasky, S., S. R. Carpenter, C. Folke, and B. Keeler. 2011. Decision-making under great uncertainty: environmental management in an era of global change. Trends in Ecology and Evolution 26(8):398-404. http://dx.doi.org/10.1016/j.tree.2011.04.007

Pontius, R. G. Jr., W. Boersma, J.-C. Castella, K. Clarke, T. de Nijs, C. Dietzel, Z. Duan, E. Fotsing, N. Goldstein, K. Kok, E. Koomen, C. D. Lippitt, W. McConnell, A. Mohd Sood, B. Pijanowski, S. Pithadia, S. Sweeney, T. N. Trung, A. T. Veldkamp, and P. H. Verburg. 2008. Comparing the input, output, and validation maps for several models of land change. Annals of Regional Science 42(1):11-37. http://dx.doi.org/10.1007/ $\underline{\mathrm{s} 00168-007-0138-2}$

Pontius, R. G., and J. Spencer. 2005. Uncertainty in extrapolations of predictive land-change models. Environment and Planning B: Planning and Design 32(2):211-230. https://doi.org/10.1068/ $\underline{\text { b3 } 1152}$

Pulver, S., and S. D. VanDeveer. 2009. "Thinking about tomorrows": scenarios, global environmental politics, and social science scholarship. Global Environmental Politics 9(2):1-13. http://dx.doi.org/10.1162/glep.2009.9.2.1

Radeloff, V. C., E. Nelson, A. J. Plantinga, D. J. Lewis, D. Helmers, J. J. Lawler, J. C. Withey, F. Beaudry, S. Martinuzzi, V. Butsic, E. Lonsdorf, D. White, and S. Polasky. 2012. Economic-based projections of future land use in the conterminous United States under alternative economic policy scenarios. Ecological Applications 22(3):1036-1049. http://dx.doi.org/10.1890/11-0306.1

Rosenthal, A., G. Verutes, E. McKenzie, K. K. Arkema, N. Bhagabati, L. L. Bremer, N. Olwero, and A. L. Vogl. 2015. Process matters: a framework for conducting decision-relevant assessments of ecosystem services. International Journal of Biodiversity Science, Ecosystem Services and Management 11 (3):190-204. http://dx.doi.org/10.1080/21513732.2014.966149

Samal, N. R., W. Wollheim, S. Zuidema, R. Stewart, Z. Zhou, M. M. Mineau, M. Borsuk, K. H. Gardner, S. Glidden, T. Huang, D. Lutz, G. Mavrommati, A. M. Thorn, C. P. Wake, and M. Huber. 2017. A coupled terrestrial and aquatic biogeophysical model of the Upper Merrimack River watershed, New Hampshire, to inform ecosystem services evaluation and management under climate and land-cover change. Ecology and Society 22(4):18. https://doi.org/10.5751/ES-09662-220418

Schmitt Olabisi, L. K., A. R. Kapuscinski, K. A. Johnson, P. B. Reich, B. Stenquist, and K. J. Draeger. 2010. Using scenario visioning and participatory system dynamics modeling to investigate the future: lessons from Minnesota 2050. Sustainability 2(8):2686-2706. http://dx.doi.org/10.3390/su2082686

Scholz, A. M. 2011. Consequences of changing climate and land use to 100-year flooding in the Lamprey River watershed of New Hampshire. Thesis. University of New Hampshire, Durham, New Hampshire, USA. [online] URL: https://www.unh.edu/unhsc/ sites/unh.edu.unhsc/files/docs/Scholz Thesis 2011.pdf

Schwartz, P. 1991. The art of the long view: planning for the future in an uncertain world. First edition. Doubleday, New York, New York, USA.

Shands, W. E. 1992. The lands nobody wanted: the legacy of the eastern National Forests. Pages 19-44 in H. K. Steen, editor. Origins of the national forests: a centennial symposium. Forest History Society, Durham, North Carolina, USA.

Sohl, T. L., M. C. Wimberly, V. C. Radeloff, D. M. Theobald, and B. M. Sleeter. 2016. Divergent projections of future land use in the United States arising from different models and scenarios. Ecological Modelling 337:281-297. http://dx.doi.org/10.1016/j. ecolmodel.2016.07.016

Stein, S. M., M. A. Carr, R. E. McRoberts, L. G. Mahal, and S. J. Comas. 2010. Threats to at-risk species in America's private forests: a forests on the edge report. General Technical Report NRS-73. U.S. Department of Agriculture Forest Service, Northern Research Station, Newtown Square, Pennsylvania, USA. https://doi.org/10.2737/NRS-GTR-73

Stein, S. M., R. E. McRoberts, L. G. Mahal, M. A. Carr, R. J. Alig, S. J. Comas, D. M. Theobald, and A. Cundiff. 2009. Private forests, public benefits: increased housing density and other pressures on private forests contributions. General Technical Report PNW-GTR-795. U.S. Department of Agriculture Forest Service, Pacific Northwest Research Station, Portland, Oregon, USA. http://dx.doi.org/10.2737/PNW-GTR-795

Sundquist, D. 2012. New Hampshire's changing landscape. Forest Notes 269:4-7. [online] URL: https://forestsociety.org/sites/ default/files/fn20121.pdf 
Swart, R. J., P. Raskin, and J. Robinson. 2004. The problem of the future: sustainability science and scenario analysis. Global Environmental Change 14(2):137-146. http://dx.doi.org/10.1016/ j.gloenvcha.2003.10.002

Tayyebi, A., B. C. Pijanowski, M. Linderman, and C. Gratton. 2014. Comparing three global parametric and local nonparametric models to simulate land use change in diverse areas of the world. Environmental Modelling and Software 59:202-221. http://dx.doi.org/10.1016/j.envsoft.2014.05.022

Thompson, J. R., D. N. Carpenter, C. V. Cogbill, and D. R. Foster. 2013. Four centuries of change in northeastern United States forests. Plos One 8(9):e72540. http://dx.doi.org/10.1371/journal. pone. 0072540

Thompson, J., K. Fallon Lambert, D. Foster, M. Blumstein, E. Broadbent, and A. Almeyda Zambrano. 2014. Changes to the land: four scenarios for the future of the Massachusetts landscape. Harvard Forest, Harvard University, Petersham, Massachusetts, USA. [online] URL: http://harvardforest.fas.harvard.edu/ changes-to-the-land

Thompson, J. R., D. R. Foster, R. Scheller, and D. Kittredge. 2011. The influence of land use and climate change on forest biomass and composition in Massachusetts, USA. Ecological Applications 21(7):2425-2444. http://dx.doi.org/10.1890/10-2383.1

Thompson, J. R., K. F. Lambert, D. R. Foster, E. N. Broadbent, M. Blumstein, A. M. Almeyda Zambrano, and Y. Fan. 2016. The consequences of four land-use scenarios for forest ecosystems and the services they provide. Ecosphere 7(10):e01469. http://dx.doi. org/10.1002/ecs 2.1469

U.S. Census Bureau. 1993. 1990 census of population and housing: population and housing unit counts. U.S. Census Bureau, Washington, D.C., USA. [online] URL: https://www.census.gov/ population/www/censusdata/90pubs/cph-2.html

U.S. Census Bureau. 2013. Summary population and housing characteristics: 2010. Report CPH-1. U.S. Census Bureau, Washington, D.C., USA. [online] URL: https://census.gov/ library/publications/2012/dec/cph-1.html

U.S. Department of Agriculture Forest Service (USDA Forest Service). 2005. Executive summary of the final environmental impact statement for the land and resource management plan: White Mountain National Forest. [online] URL: https://www.fs.usda. gov/Internet/FSE DOCUMENTS/stelprdb5200020.pdf

U.S. Department of Agriculture National Agricultural Statistics Service (USDA-NASS). 2012. 2012 census of agriculture: New Hampshire: state and county data. U.S. Department of Agriculture National Agricultural Statistics Service, Washington, D.C., USA. [online] URL: https://www.agcensus.usda.gov/ Publications/2012/Full_Report/Volume_1, Chapter_1_State_Level/ New Hampshire/nhv1.pdf

U.S. Department of Agriculture National Resources Conservation Service (USDA-NRCS), U.S. Geological Survey, and U.S. Environmental Protection Agency. 2015. Watershed boundary dataset for HUC10, New Hampshire. U.S. Department of Agriculture National Resources Conservation Service, Washington, D.C., USA. [online] URL: http://datagateway.nrcs. usda.gov
U.S. Environmental Protection Agency (USEPA). 2009. Land-use scenarios: national-scale housing-density scenarios consistent with climate change storylines (final report). USEPA, Global Change Research Program, National Center for Environmental Assessment, Washington, D.C., USA. [online] URL: https:// cfpub.epa.gov/ncea/risk/recordisplay.cfm?deid=203458

van Vliet, J., A. K. Bregt, D. G. Brown, H. van Delden, S. Heckbert, and P. H. Verburg. 2016. A review of current calibration and validation practices in land-change modeling. Environmental Modelling and Software 82:174-182. http://dx.doi.org/10.1016/j. envsoft.2016.04.017

Verburg, P. H., A. Tabeau, and E. Hatna. 2013. Assessing spatial uncertainties of land allocation using a scenario approach and sensitivity analysis: a study for land use in Europe. Journal of Environmental Management 127:S132-S144. http://dx.doi. org/10.1016/i.jenvman.2012.08.038

Vermont Sustainable Jobs Fund. 2013. Farm to plate strategic plan. Vermont Sustainable Jobs Fund, Montpelier, Vermont, USA. [online] URL: http://www.vtfarmtoplate.com/plan/

Vitousek, P. M., H. A. Mooney, J. Lubchenco, and J. M. Melillo. 1997. Human domination of Earth's ecosystems. Science 277 (5325):494-499. http://dx.doi.org/10.1126/science.277.5325.494

Wake, C. P., M. Frades, M. Magnusson, R. Gittell, C. Skoglund, J. Morin, and G. Hurtt. 2011. Collaborative and transparent: production of decision-relevant information for New Hampshire's climate action plan. Northeastern Geographer 3:1-26. [online] URL: http://aagnestval.wpengine.com/wpcontent/uploads/2015/09/Collaborative-Transparent.pdf

Walsh, J., D. Wuebbles, K. Hayhoe, J. Kossin, K. Kunkel, G. Stephens, P. Thorne, R. Vose, M. Wehner, J. Willis, D. Anderson, S. Doney, R. Feely, P. Hennon, V. Kharin, T. Knutson, F. Landerer, T. Lenton, J. Kennedy, and R. Somerville. 2014. Our changing climate. Pages 19-67 in J. M. Melillo, T. C. Richmond, and G. W. Yohe, editors. Climate change impacts in the United States: the third national climate assessment. U.S. Global Change Research Program, Washington, D.C., USA. http://dx.doi. org/10.7930/J0Z31WJ2

Wear, D. N. 2011. Forecasts of county-level land uses under three future scenarios: a technical document supporting the Forest Service 2010 RPA assessment. General Technical Report SRS-141. U.S. Department of Agriculture Forest Service, Southern Research Station, Ashville, North Carolina, USA. [online] URL: https:// www.fs.usda.gov/treesearch/pubs/39404

Wickham, J. D., S. V. Stehman, J. A. Fry, J. H. Smith, and C. G. Homer. 2010. Thematic accuracy of the NLCD 2001 land cover for the conterminous United States. Remote Sensing of Environment 114(6):1286-1296. https://doi.org/10.1016/j.rse.2010.01.018 


\section{Appendix 1: Qualitative Methodology}

To capture the views of a broad range of stakeholders, we conducted key informant interviews with representatives from five sectors: environmental nonprofits, business and industry, timber interests, public sector agencies, and academics and natural resource management consultants (Table 1). Key informant interviews do not commonly require the production of numerically representative sample for each sector or of the stakeholder community as a whole, but rather provide a range of information and perspectives from stakeholders with specialized knowledge and/or decision-making power (Frey and Fontana 1991, Marshall 1996a, 1996b).

We identified key informants based upon our knowledge of the state and upon recommendations from individuals in leadership positions, and invited them to participate in facilitated group interviews. We conducted thirteen interviews, cumulatively including between five and twenty representatives from each sector. Interviews were commonly 90 minutes long. Prior to the interviews, key informants signed a UNH Institutional Review Board approved Consent Form. The interviews focused on discussion of two questions: 1) describe a picture of what you would like New Hampshire to look like in the future, two to four decades or more from now; and 2) describe a picture of what you expect New Hampshire to look like in the future, two to four decades or more from now. These questions were designed to encourage a discussion of opposing views of the future. Notes from the interviews were shared within the research team, compared for accuracy, and then qualitatively analyzed, with participants' responses and perspectives categorized by theme.

\section{LITERATURE CITED}

Frey, J. H., and A. Fontana. 1991. The group interview in social research. The Social Science Journal 28(2):175--187.

Marshall, M. N. 1996a. Sampling for qualitative research. Family practice 13(6):522-526.

Marshall, M. N. 1996b. The key informant technique. Family Practice 13(1):92--97. 


\section{Appendix 2: Details of map generation}

Maps for each scenario were generated using custom land cover change models. Details of these models varied by scenario, but, following the methods of Thompson et al. (2011), all simulations used regression tree (RT) models to distinguish among zones with different probability of land cover change and conservation during the 1996 to 2011 interval. Population and impervious cover maps were generated by combining these maps with the accompanying population trajectories. Details of model construction are presented below, beginning with an overview of the use of RTs and the general approach for producing population and impervious cover maps. Subsequent subsections present the model details for the Linear, Backyard, and Community scenarios.

\section{General methods}

RTs are non-parametric models used to relate a single response variable to categorical and numeric independent variables by recursive binary partitioning of input data into more homogeneous groups (De'ath and Fabricius 2000). The predictor variables supplied to the the RTs varied somewhat by scenario, but generally included: 1996 land cover categories, elevation, slope, soil drainage classification, prime farmland classification, and distances from major roads, developed land, conserved land, surface water, and the population centers of different sized communities (Table A2.1). Size classes for communities were determined from visual inspection of natural breaks in the distribution of town sizes in the state. We excluded predictor variables that were likely to change over the interval from 2010-2100 but which could not be simulated as a simple function of changing land cover. For instance, because some of our scenarios include the construction of new roads in residential subdivisions, we excluded distance from minor roads as a driver in our analyses. We also deliberately excluded population densities and population growth rates as possible driving variables in our statistical models because of the difficulty of disentangling the degree to which population drives development from the degree to which development drives population growth.

Following the methods of Thompson et al. (2011), we generated RTs in the software package R version 3.2.2 (R Core Team 2015), using the conditional inference tree toolset implemented in the R package PARTY (Hothorn et al. 2006). Spatial coverages for all input variables were derived from the GRANIT database (NH GRANIT 2016), and all spatial analyses were conducted using the R packages RASTER (Hijmans 2015) and RGDAL (Bivand et al. 2015). Raw data on land cover change were derived from land cover maps based on data from the National Oceanic and Atmospheric Administration's National Coastal Change Analysis Program (NOAA C-CAP) 1996 and 2011 (NOAA 2014), enhanced by Rubin and Justice (unpublished data). The 2011 map was also used as the base map for our simulations. Spatial patterns of land conservation were estimated from dates of land conservation in the NH GRANIT Conservation/Public Lands dataset, with additional dates of land conservation obtained from a query of a land transactions database maintained by the New Hampshire Department of Resources and Economic Development (NH DRED). 
Table A2.1. Variables included in regression tree models

\begin{tabular}{|c|c|c|}
\hline Variable & Source & Notes \\
\hline Land cover & $\begin{array}{l}\text { NOAA C-CAP } 1996 \text { and } 2011^{1} \text { enhanced by } \\
\text { NH GRANIT }^{2}, 2014\end{array}$ & $\begin{array}{l}\text { Source categories aggregated to: } \\
\text { forest, agriculture, development, } \\
\text { wetland, water, and other }\end{array}$ \\
\hline Distance from developed land & NOAA C-CAP 1996 and 2011 ${ }^{1}$ & \\
\hline Distance from surface water & NOAA C-CAP 1996 and $2011^{1}$ & \\
\hline Conserved land & $\begin{array}{l}\text { NH GRANIT: New Hampshire } \\
\text { Conservation / Public Lands }{ }^{3}\end{array}$ & $\begin{array}{l}\text { Dates of conservation } \\
\text { supplemented with NH DRED } \\
\text { database query }\end{array}$ \\
\hline Distance from conserved & $\begin{array}{l}\text { NH GRANIT: New Hampshire } \\
\text { Conservation / Public Lands }{ }^{3}\end{array}$ & \\
\hline Elevation & USGS National Elevation Dataset ${ }^{4}$ & \\
\hline Slope & USGS National Elevation Dataset ${ }^{4}$ & \\
\hline Soil drainage classification & $\begin{array}{l}\text { NH GRANIT: Soil Survey Geographic } \\
\text { (SSURGO) database for New Hampshire }\end{array}$ & \\
\hline Flood plain classification & Digital Flood Insurance Rate Maps ${ }^{3}$ & \\
\hline Farmland classification & $\begin{array}{l}\text { NH GRANIT: Soil Survey Geographic } \\
\text { (SSURGO) database for New Hampshire }{ }^{3,5}\end{array}$ & \\
\hline Distance from major roads & NH GRANIT: NH Public Roads ${ }^{3}$ & \\
\hline $\begin{array}{l}\text { Distance from population } \\
\text { centers and municipalities of } \\
\text { different size classes }\end{array}$ & $\begin{array}{l}\text { NH GRANIT: New Hampshire Political } \\
\text { Boundaries }{ }^{3} \text {, U.S. Census Populations } \\
\left(1990,2000 \text {, and 2010) }{ }^{5} \text { and U.S. Census }\right. \\
\text { Populated Places from USGS Geographic } \\
\text { Names Information System (GNIS) }^{6}\end{array}$ & $\begin{array}{l}\text { Classes included: all NH } \\
\text { population centers; all NH } \\
\text { municipalities; all NH } \\
\text { municipalities with population } \\
\text { above 500; all NH municipalities } \\
\text { with pop above 8000; Manchester } \\
\text { and Nashua; Boston MA }\end{array}$ \\
\hline
\end{tabular}

To model the geographical distribution of land change and conservation within the state, RT models for geographic predictors of each change category were developed based on a randomly positioned uniform grid of sample points. In most cases the spacing of sample points was $1 \mathrm{~km}$. Land categorized by NOAA C-CAP as wetland, surface water, or developed land, and conserved land were excluded from the development and conservation models.

For each change category, RTs were used to identify geographic zones corresponding to the terminal nodes of each tree. The resulting maps of probability zones were the basis for the land cover change simulations. For each land change category, we calculated area of change within each zone between 1996 to 2011, allocated among zones as $30 \mathrm{~m}$ grid cells based on the percent of total land change that had occurred in each zone in 1996 to 2011. In cases where regression 
trees included distance from development or distance from conserved land as driving variables, zones were re-calculated each decadal time step. When a zone did not contain sufficient undeveloped or un-conserved land area to accommodate a land change increment, the remaining increment was allocated among other zones. Specific details of this process varied by scenario.

Maps of population density and percent impervious surface were derived from the $30 \mathrm{~m}$ resolution land cover maps for each scenario, combined with base maps of current population density and assumptions about population growth that varied by scenario (Fig. A2.1). The base map for population density was a rasterization of 2010 U.S. Census block-level population densities. For each decadal time step, the resulting population density map was updated based on the scenario-specific assumptions about how population is spatially allocated.

\section{Population}

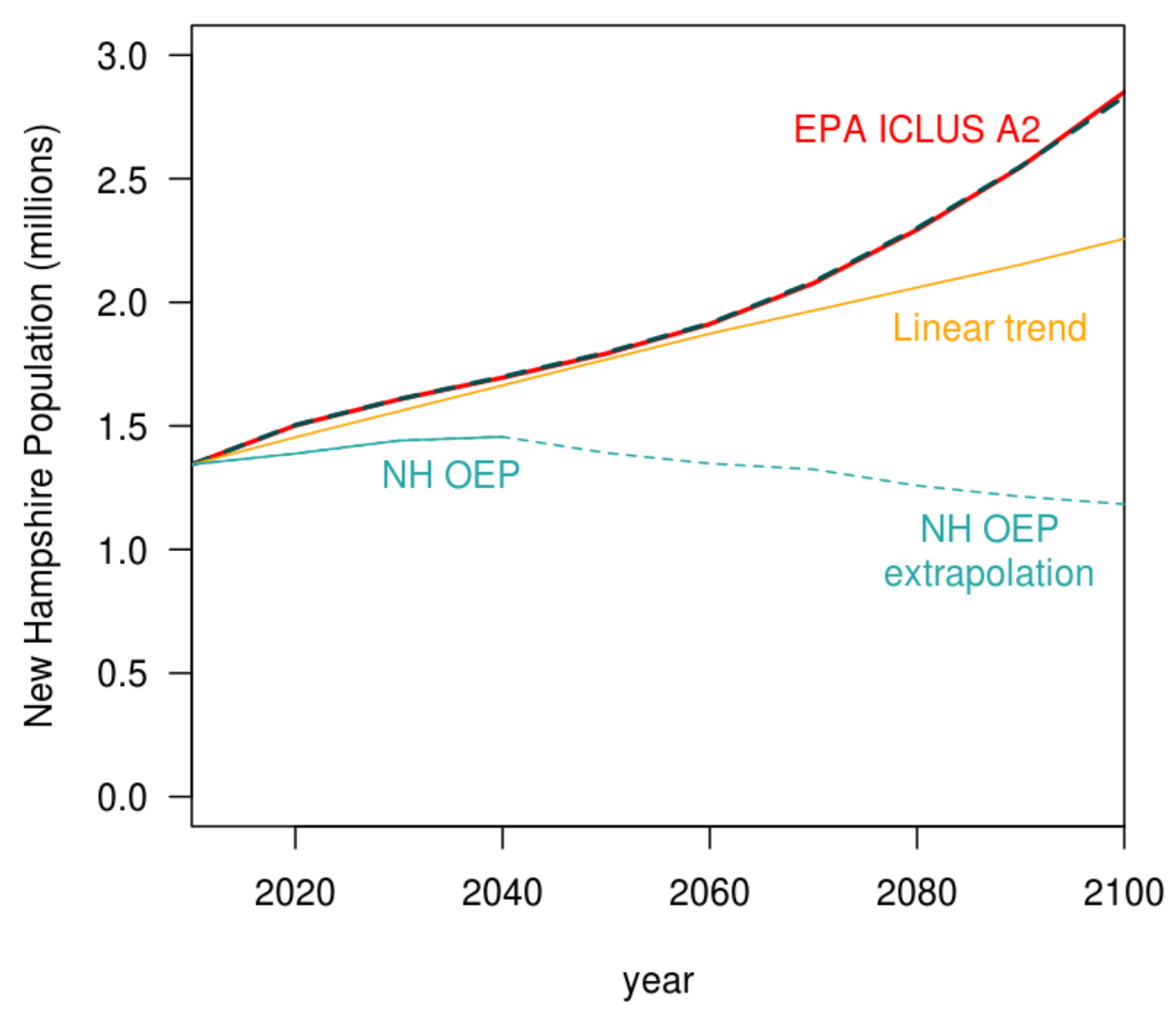

Fig. A2.1. The three New Hampshire population trajectories used in the scenarios: ICLUS A2, the EPA ICLUS population projection for the IPCC A2 scenario (EPA ICLUS), a linear extrapolation of 1990-2010 population trends (Linear trend), and NH Office of Energy and Planning (NH OEP) with projection out to 2100 (NH OEP extrapolation). 
Impervious cover maps were generated by combining the National Land Cover Database (NLCD) impervious surface map for 2011 (Xian et al. 2011) with the simulated change in population density for each time step. A saturation curve was fit to the relationship between mean impervious cover and population density of U.S. Census tracts by non-linear least squares regression to produce a function relating percent impervious cover $(I)$ to population density $(P)$ : $I=100 * 0.00055 * P /(1+0.00055 * P)$. Details of how this function was used varied by scenario.

\section{Scenarios}

\section{Linear Trends}

Annual land cover change in each category is maintained at 1996-2011 rates through 2100, and conservation rates are maintained at 1996-2011 rates until 2060. Each decade, $102 \mathrm{~km}^{2}$ of land is permanently converted from undeveloped to developed, $12 \mathrm{~km}^{2}$ is converted to agricultural land, and $0.5 \mathrm{~km}^{2}$ of agricultural land reverts to forest. Until 2060, $806 \mathrm{~km}^{2}$ of undeveloped land is permanently conserved each decade. To reflect the common perception of key informant stakeholders that different parts of New Hampshire are subject to different drivers of land cover change (see Johnson 2012), the spatial distribution of land cover change and conservation were determined independently for each of four regions in the state: North (Coos and Carroll counties), Central (Grafton, Belknap, Merrimack, and Strafford counties), Southwest (Sullivan and Cheshire counties), and Southeast (Hillsborough and Rockingham counties).

We generated RTs for development and conservation within each region (see for example regional development RTs in Fig. A2.2). Because 1996-2011 development rates in the North and Southwest were very low, a $500 \mathrm{~m}$ grid, instead of a $1 \mathrm{~km}^{2}$ sample grid, was used in those regions to increase the number of sample points that had new development during that interval. The resulting regional maps of probability zones were then combined into single maps (one for development and one for conservation) to determine the allocation of newly developed and newly conserved land across the state as $30 \mathrm{~m}$ grid cells in each decadal time step. Spatial projections for land cover change in the forest-to-agriculture and agriculture-to-forest categories were determined by a single statewide RT for each category.

To calculate population density maps, the population of New Hampshire was assumed to increase at a rate of 10,000 people per year, giving a total of 2.2 million people in the state by 2100, a linear extrapolation of 1990-2010 trends (Fig. A2.1). Because this new population was assumed to be uniformly distributed across newly developed land, each decade the population density increased by $96 / \mathrm{km}^{2}$ (=100,000 people / $104 \mathrm{~km}^{2}$ ) for every newly developed pixel. In each time step, the impervious cover for newly developed pixels was calculated based on the new population density for that pixel. The population density and impervious cover for all other cells was assumed not to change. 


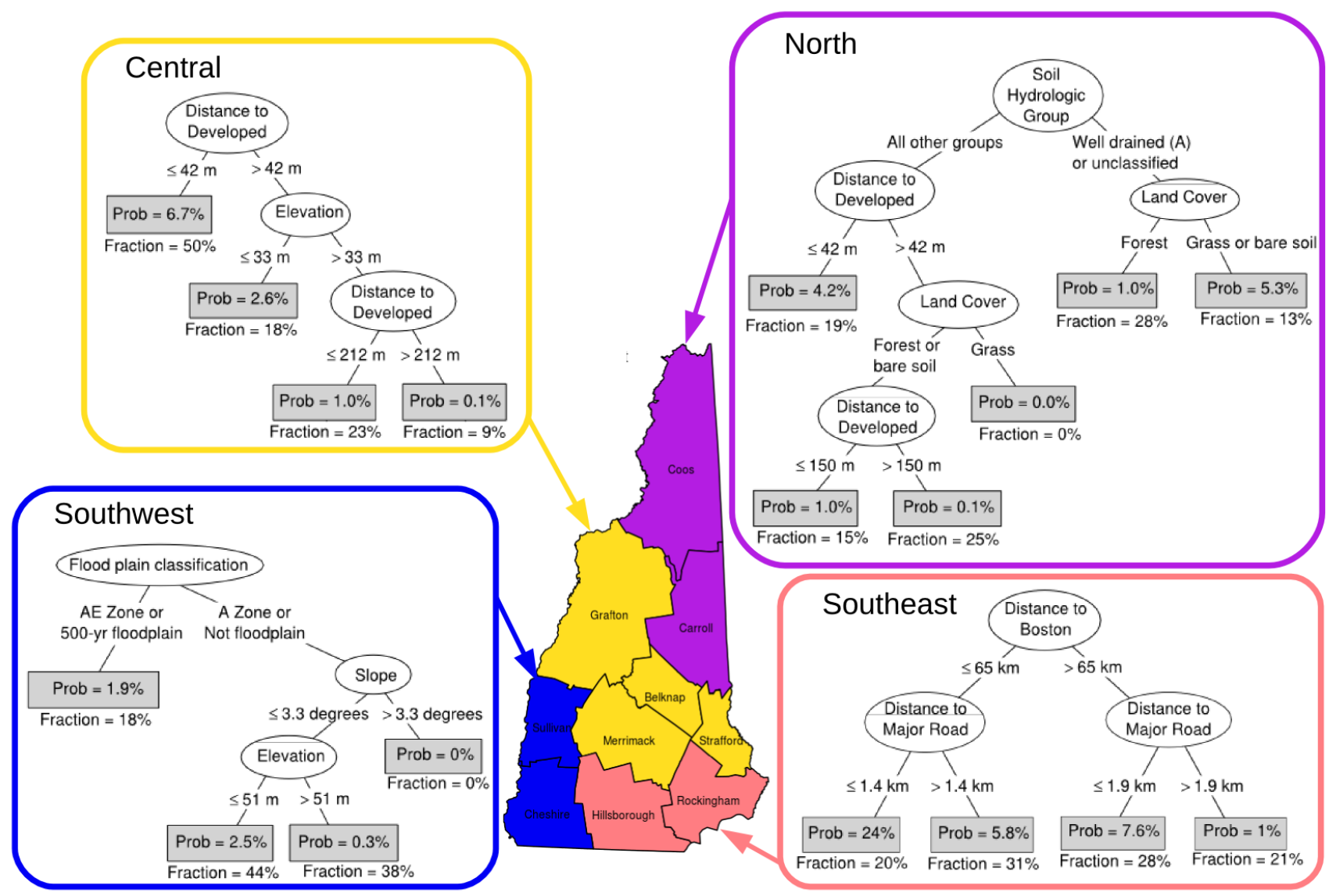

Fig. A2.2. Example regression trees (RTs) for development in regions of New Hampshire. RTs are shown used to generate zones of varied probability of development within the Central, North, Southwest, and Southeast regions of the state. Significant predictor variables are shown in the ovals, thresholds used to separate the zones are shown on the lines, probability of development is shown in the gray boxes, and the fraction of development occurring within each zone is shown below the boxes. These RTs were used for the Linear scenario. Similar trees were used to predict conservation, forest conversion to agriculture, and agriculture conversion to forest in each scenario.

\section{Backyard Amenities}

The area of newly developed land was determined separately for each municipality based on projected population growth, the typical lot sizes in each municipality, and the assumption (based on previous experience in southern New Hampshire; Michell et al. unpublished report) that residential zoning would shift toward cluster zoning as each community fills.

Municipal population growth projections were adapted from the EPA ICLUS scenario A2 for county-level population growth (U.S. EPA 2009, Bierwagen et al. 2010). Under this projection, the total NH population grows from the current 1.3 million (for 2014) to 1.8 million by 2050 and 2.8 million by 2100 (Fig. A2.1), with the vast majority of population growth in southeastern counties. We modified the ICLUS A2 population scenario by adjusting allocation among 
counties to allow suburban sprawl in high density counties to spill over into municipalities in neighboring counties and northward along major roads (I-89, I-93, and NH Route 16). This reflects previous findings suggesting that the areas of most rapid growth tend to be progressively further from urban centers as buildout occurs (e.g., Mockrin et al. 2012, Jeon et al. 2014, Thorn et al. 2016), as well as key informant perspectives on likely patterns of future development. Within most counties, we initially distributed population among municipalities in proportion to the current municipal population. We used special handling for Grafton county, a primarily rural county with two major population centers that had been identified by stakeholders as areas with high potential for growth. We therefore assumed that all growth in the county would initially be concentrated in those population centers (Hanover/Lebanon and Plymouth), with additional growth occurring as spillover population from other counties.

Within municipalities, the area of development required for the increase in population for each decadal time step was calculated assuming 2.5 people per housing unit and one housing unit per residential lot. Residential lot size for each municipality was initially set to the mean lot size based on 2014 zoning but was allowed to change dynamically in response to development pressure, based on analysis by Mitchell et al. (unpublished report). Specifically, when a municipality is $50 \%$ built out, it is assumed that mandatory cluster development zoning is adopted. Lot sizes are halved, and for every acre that is developed, an acre of land is set aside for conservation. When a municipality is $62.5 \%$ developed, more extreme cluster zoning was assumed, with lot sizes halved again and three acres set aside for conservation for every acre that is developed.

As municipalities run out of land that can be developed in the simulation, the excess population is distributed among nearby municipalities, based on a gravity model generated from a simple transportation cost-distance map. The cost of travel (e.g. in the form of commuting time) along the major roads was assumed to be half the cost of travel elsewhere on the map. The costdistance map was produced from a raster map of major roads (see Table A2.1) using the $\mathrm{R}$ function COSTDisTANCE from the package GDISTANCE (van Etten 2015). Minor roads were not included as low-cost pathways because we assumed that new roads would be constructed to accommodate new development. Under the gravity model, the probability of spill-over population from a filled municipality going to each other municipality in the state scales with the inverse of the square of the cost-distance between the two (see Wang 2001). The excess population is then allocated by drawing from the resulting probability distribution for municipalities that are not yet filled.

Within municipalities, development and conservation are spatially allocated according to RTs generated for the entire state of New Hampshire. Because New Hampshire municipalities are typically only five to fifteen kilometers across, the driving variables that were most important at larger spatial scales were excluded from the RT analysis. Specifically, we excluded elevation and the distances from major roads, populated places, municipalities of different sizes, and surface water. Other land conversion (forest or other to agriculture and agriculture to forest) was allocated at the statewide level using the same regression trees as the Linear scenario.

Population density maps were generated from the population density base map by combining municipal population projections with development maps. In municipalities with a positive 
population increment, the population density increment for all newly developed land was defined as equal to the population increment for that municipality, divided by the developed land increment for the municipality that time step; in municipalities with a negative population increment, all land area within the municipality was assumed to decrease in population density by the same proportion as the decrease in municipal population as a fraction of previous population.

Impervious cover for newly developed pixels was then calculated from population density by applying the function for percent impervious cover for each newly developed cell. Impervious cover in other parts of the state was assumed not to change.

\section{Community Amenities}

In the Community family of scenarios, all land development is assumed to occur as redevelopment, so the simulated area of developed land does not change. Patterns of land cover change between forests and agriculture differed between the Wildlands and Food scenarios. For the Wildlands land cover change scenario, we assumed rates of conversion from forest or other to agriculture and agriculture to forest were the same as in the Linear scenario, and used the same regression trees to simulate land cover change. For the Food scenario, land was assumed to be converted to agriculture at a constant rate such that by the year 2060 there are a total of 3,640 $\mathrm{km}^{2}$ (900,000 acres) of farmland and pasture in the state of New Hampshire, as described in the Omnivore's Delight scenario (Donahue et al. 2014). To accomplish this, $510 \mathrm{~km}^{2}$ of forest is converted to farmland each decade. The spatial distribution was determined by the same RT as for the Linear scenario, but constrained to areas identified as prime farmland, prime farmland of state-wide importance, or prime farmland of local importance as identified by the Soil Survey Geographic (SSURGO) soils map (see Table A2.1). We assumed no additional change in agricultural land cover after 2060 and that no farmland reverted to forest.

In all scenarios, conservation was assumed to occur at a constant rate such that by the year 2060, all high priority conservation lands identified by the New Hampshire Wildlife Action Plan (WAP), The Nature Conservancy (TNC) New Hampshire portfolio plans and The Society for Protection of New Hampshire Forests (SPNHF) priority lands for conservation have been conserved, giving a total of $12,000 \mathrm{~km}^{2}$ of conserved land in the state. For each decadal timestep, $1,203 \mathrm{~km}^{2}$ of undeveloped land is conserved, using the same regression tree as for the Linear scenario, but constrained to the combination of habitat designated Tier 1 by NH WAP with the highest priority land targeted for conservation by the SPNHF and TNC conservation plans for 2014 and 2013 respectively (NH Fish and Game 2005, TNC 2013, SPNHF unpublished data).

Calculation of future population density depends on the population growth scenario (Fig. A2.1). In the Large Community scenario, the same municipal-level population growth pattern is assumed is assumed to be the same as for the Backyard scenario. For the Small Community scenario, we used county-level population projections developed by the NH Office of Energy and Planning (OEP) for 2010-2040 (NH OEP 2014), extrapolated out to 2100 (Bob Scardamalia, RLS Demographics, personal communication). Within counties, new population was allocated among municipalities based on existing population, as was the case for the Large Community scenario. 
In both population scenarios, population growth within municipalities is accommodated by redevelopment of currently populated developed land. These areas were identified as $30 \mathrm{~m}$ cells of developed land with population density greater than 156 people $/ \mathrm{km}^{2}$ (the estimated population density with 4 acre lots) and less than 20,000 people $/ \mathrm{km}^{2}$ (the population density of the larger apartment blocks in downtown Manchester, NH), and for which the new population density would not exceed 30,000 people $/ \mathrm{km}^{2}$. If no land area met these requirements, the minimum population density was lowered first to include all developed cells with density greater than 0 , and then, if necessary, to include all developed cells. In municipalities with positive population growth, the population density increment for previously developed land area is defined as the population increment for the municipality as a whole divided by the total area identified as available for growth, and other cells did not change in population density; for municipalities with negative population growth, the protocol for changing population density was the same as for the Backyard scenario.

Impervious cover for developed land was assumed to increase with increasing population density as larger residential structures are constructed, and to decrease with decreasing population density as unused buildings and pavement are cleared to make way for parks and gardens. To accomplish this, the impervious cover regression model was first applied to all cells with changing population density to give a preliminary map of new impervious cover. The resulting coverage was compared with the impervious cover for the previous time step, and the new map was used to replaced the previous map for all cells for which either the population density decreased or both population density and impervious cover increased.

\section{LITERATURE CITED}

Bierwagen, B. G., D. M. Theobald, C. R. Pyke, A. Choate, P. Groth, J. V. Thomas, and P. Morefield. 2010. National housing and impervious surface scenarios for integrated climate impact assessments. Proceedings of the National Academy of Sciences 107(49):20887-20892.

Bivand, R., T. Keitt, and B. Rowlingson. 2015. rgdal: Bindings for the Geospatial Data Abstraction Library. R package version 0.9-2.

De’ath, G., and K. E. Fabricius. 2000. Classification and Regression Trees: A Powerful Yet Simple Technique for Ecological Data Analysis. Ecology 81(11):3178.

Donahue, B., J. Burke, M. Anderson, A. Beal, T. Kelly, M. Lapping, H. Ramer, R. Libby, and L. Berlin. 2014. A New England Food Vision. Page 44. Food Solutions New England.

van Etten, J. 2015. gdistance: Distances and Routes on Geographical Grids. R package version 1.1-9.

Hijmans, R. J. 2015. raster: Geographic Data Analysis and Modeling. R package version 2.3-40. Hothorn, T., K. Hornik, and A. Zeileis. 2006. Unbiased Recursive Partitioning: A Conditional Inference Framework. Journal of Computational and Graphical Statistics 15(3):651-674.

Jeon, S. B., P. Olofsson, and C. E. Woodcock. 2014. Land use change in New England: a reversal of the forest transition. Journal of Land Use Science 9(1):105-130.

Johnson, K. M. 2012. New Hampshire Demographic Trends in the Twenty-First Century. Page 31. Carsey Institute, University of New Hampshire, Durham, New Hampshire. 
Mockrin, M. H., S. I. Stewart, V. C. Radeloff, R. B. Hammer, and K. M. Johnson. 2012. Spatial and temporal residential density patterns from 1940 to 2000 in and around the Northern Forest of the Northeastern United States. Population and Environment 34(3):400-419.

NH Fish and Game. 2005. New Hampshire Wildlife Action Plan.

NH GRANIT. 2016. New Hampshire’s Statewide GIS Clearinghouse. http://granit.unh.edu/.

NH Office of Energy and Planning. 2006. Geographic Names Information System (GNIS). http://www.granit.unh.edu/data/search?dset=gnis/nh.

NH Office of Energy and Planning. 2011. Population of New Hampshire Towns and Counties 1960-2010. Accessed September 2017 at https://www.nh.gov/osi/datacenter/census/documents/population-towns-counties-1960-2010.csv.

NH Office of Energy and Planning. 2014. County Population Projections, 2013 by Age and Sex.

NOAA, Office for Coastal Management. C-CAP New England 1996-2010-Era Land Cover Change. Coastal Change Analysis Program (C-CAP) Regional Land Cover. Charleston, SC: NOAA Office for Coastal Management. Accessed September 2014 at www.coast.noaa.gov/ccapftp.

R Core Team. 2015. R: A Language and Environment for Statistical Computing. R Foundation for Statistical Computing, Vienna, Austria.

Thompson, J. R., D. R. Foster, R. Scheller, and D. Kittredge. 2011. The influence of land use and climate change on forest biomass and composition in Massachusetts, USA. Ecological Applications 21(7):2425-2444.

Thorn, A., J. Thompson, and J. Plisinski. 2016. Patterns and Predictors of Recent Forest Conversion in New England. Land 5(3):30.

TNC (The Nature Conservancy, NH Chapter). 2013. Ecoregional Portfolio Conservation Focus Areas.

U.S. EPA. 2009. Land-Use Scenarios: National-Scale Housing-Density Scenarios Consistent with Climate Change Storylines (Final Report). EPA, Global Change Research Program, National Center for Environmental Assessment, Washington D.C.

USGS. 2009. National Elevation Dataset (NED). https://nationalmap.gov/.

Wang, F. 2001. Regional density functions and growth patterns in major plains of China, 19821990*. Papers in Regional Science 80(2):231-240.

Xian, G., C. Homer, J. Dewitz, J. Fry, N. Hossain, and J. Wickham. 2011. The change in impervious surface area between 2001 and 2006 in the conterminous United States. Photogrammetric Engineering and Remote Sensing 77(8):758--762. 


\section{Appendix 3: Scenario narratives}

The following narratives provide general descriptions of changes to New Hampshire's economy and culture that could change under each scenario: Backyard, Linear, and the four scenarios in the Community family.

\section{Backyard}

Rapid population growth is combined with traditional zoning and a rollback of policies and practices to protect natural landscapes and ecosystem services (outside of areas already conserved). The policy and practice of local control dominates in municipalities, the legislature, and courts. Less public money is available for land protection, and environmental statutes and regulations are weakened. New land protection agreements are challenged in court and are increasingly at risk, although no previously conserved land is developed. Financial incentives encourage landowners to make forested and agricultural land available for industrial parks and residential subdivisions.

The primary form of land cover change is residential development, primarily houses adjoining private lawns, gardens, or small wooded lots. Lot sizes are determined by municipal zoning similar to the present day (i.e., one to two acre lots in most communities; Mitchell et al. unpublished report). Housing development occurs primarily in the southeast, an area with easy access to the Boston-metro region. As the southeastern municipalities fill up, development spills northward along major highways (I-89 and 93) and into the southwest and central regions of the state.

Conservation of forests and farmland is reactive, not proactive. As municipalities surpass 50\% development, each community undergoes a cultural shift that drives policies to favor cluster zoning (reflecting current trends; Mitchell et al. unpublished report). Cluster zoning supports a decrease in lot sizes, and one to three acres are set aside for conservation for every acre that is developed. Conserved areas are locally managed, with emphasis on recreation and aesthetic values, rather than on other ecosystem services such as wildlife habitat, carbon sequestration, or water supply or flood control.

Residential development occurs primarily outside of urban cores where land costs are lower and municipal services lacking. Homes rely on wells and septic systems rather than municipal water and sewer, and the automobile is the primary form of transportation. Road building does not keep pace with the increase in vehicle miles traveled (VMT); as a result, commuters spend increased time in traffic. Meanwhile, the high cost for municipalities of even the limited road construction and other dispersed infrastructure leaves few resources for other strategic investments. Most economic growth is in the construction and service sectors. There is no state-wide energy plan. Forests cleared in pre-development liquidation harvests provide a one-time source of biomass energy. Lowest cost energy prevails.

The composition of undeveloped land remains similar to the present day, mostly forest with a small amount of agriculture (mostly hay and pasture). Forestry remains highly mechanized, and forestry and agricultural practices focus on short-term profit with reduced emphasis on erosion 
mitigation, minimization of fertilizer inputs, or impact on ecosystem services.

\section{Linear}

The Linear scenario represents a future with economy, practices, and rates of change similar to those over the period from the 1990s to 2010. Preference for local control, resistance to policy change at the municipal level, and traditional business interests are counterbalanced by continued activity by the local and regional land trusts and a growing cultural value of protection of forests, farmland, and ecosystem services, producing a mixture of conventional development and expanding land conservation.

Rates of land cover change among forest, developed, and agricultural categories are held constant at the average rate from 1996 to 2011, and statewide population growth is a linear extrapolation of 1990 to 2010 rates. Rates of land conservation continue linearly as well, but because rates of conservation during the 1996 to 2011 interval were unusually high (Meyer et al. 2014), we assume that those rates of conservation will end by the year 2060. The spatial distribution of land cover change and conservation is shaped by the same drivers as for 19962011, and the spatial distribution of the growing population corresponds to the distribution of new development.

Public funding for roads continues to lag behind needs (e.g., Haven 2013), so few new roads are built. There is a modest increase of within-community public transit and public water and sewer, but most residents continue to rely on personal automobiles and wells and septic systems. There are slight expansions in low impact development technologies and the use of renewable energy.

In northern New Hampshire, highly mechanized forestry remains prominent, driven by commercial timber interests. Aside from Best Management Practices to minimize erosion (North East Foresters Association 2013), sustainable forestry practices are rare outside of conserved areas with a specific sustainable timber mission. Uneven-age management with passive regeneration continues to be the norm. Additional timber harvests occur throughout the state where land is cleared in preparation for subdivision development. Agricultural practices are similar to the present day.

\section{Community}

In this family of scenarios, public attitudes shift toward valuing collective needs at state and regional scales and away from focus on the particular desires and needs of individuals, aligning with the recommendations of NH's 2009 Climate Action Plan (New Hampshire Climate Policy Task Force 2009). Policies and investment support conservation of land for working forests and agriculture and for the growth of renewable energy. Universal buffer regulations protect wetlands and surface waters across the state. Statewide coordinated policies are implemented to ensure safety, connectivity, and access regardless of age, ability, or mode of transportation.

No additional land is developed beyond what is already developed. Instead, in areas with growing population, urban cores and village centers are redeveloped to accommodate expanding populations. In areas where the population declines, abandoned residences and businesses are 
converted into public parks and gardens. Redevelopment to increase density takes various forms, including second houses added to one and two acre lots and construction of apartments, condos, and co-housing in village centers, in alignment with the recent passage of NH Senate Bill 164 (2016) on Accessory Dwelling Units. Most redevelopment uses the principles of low impact design (LID; Roseen et al. 2011), which protects or enhances ecosystem services.

Conservation of forests and farmland is strategic and proactive, with new conservation including rare habitats and corridors between existing conserved land.

Substantial public funds are allocated to building and maintaining public and non-motorized transportation infrastructure between and within population centers. Walking and riding miles increase while VMT decrease, resulting in less congestion, even in growing urban centers. The number of roads therefore does not need to be increased. Concentrated redevelopment also facilitates expansion of public water and sewer because fewer pipe-miles are required to provision additional paying users. Sewage managed by centralized facilities is converted to fertilizer.

Use of sustainably harvested biomass fuels in the state increases, primarily for heating and cogeneration facilities. Hydroelectric energy increases in the form of run-of-river and small generators, even as dams are removed to enhance fish habitat. Large tracts of land are set aside for renewable energy projects (biofuel, wind, solar, geothermal).

Forests and farmland are managed to maximize ecosystem services and minimize environmental degradation. Forestry across the state shifts toward more deliberate management - similar to the current management policies in the White Mountain National Forest (USDA 2005) - with different goals in different locations. Location-specific goals could include: maximized wood production, increased carbon storage, habitat connectivity, habitat diversity, erosion minimization, water quality, and flood mitigation. Agricultural land is managed for high productivity, carbon sequestration, well-being of desirable wildlife, and minimized inputs, soil degradation, and runoff. Integrated Pest Management and agroecological methods are emphasized.

Within the Community family, population growth and intensity of redevelopment differs between the Large Community and Small Community variants, and land cover change outside of developed areas differs between the Food and Wildlands variants (see below). The population scenarios and land cover scenarios can be combined to give a total of four scenarios in the family: Large Community - Wildlands, Small Community - Wildlands, Large Community Food, and Small Community - Food.

\section{Large Community}

New Hampshire's population grows rapidly, especially in the more populous towns and cities of the southeastern counties and along major highways. Because no existing forest or farmland is developed, the population densities in these communities increase dramatically, greatly increasing the efficiency of municipal services and freeing financial resources for strategic investments in education and workforce development. The technology sector expands rapidly, 
further contributing to the economic, social, and cultural vitality of town centers (Gittell and Orcutt 2012), and attracting young, upwardly-mobile families and aging seniors. The overall scenario reflects a recent demographic trend across America away from suburban sprawl and towards revitalized multi-use pedestrian-friendly urban landscapes (e.g., Ehrenhalt 2012), combined with proactive policies to ensure a high percentage of affordable housing in cities and village centers (Addison et al. 2013, Johnson and Talen 2008).

\section{Small Community}

Population growth in the early 21st century is modest, followed by a gradual decline driven by lower fertility rates and an older population (NH OEP 2014). Population change (both positive and negative) primarily occurs in the Southeastern counties (Hillsborough, Rockingham, and Merrimack). For most other counties, the population holds steady, but the population of Coos county declines throughout the century. Community-oriented values promote smart-growth development similar to the Large Community scenario, but because the population remains relatively constant the small-town character of New Hampshire municipalities is generally preserved. In areas where the population declines, abandoned residences and box stores are converted into public parks and gardens, producing extensive shared green space or sites for renewable energy to complement improved urban amenities provided by mixed-use zoning and walkable streets. Public water, sewer, and transit expand, but more modestly than in the Large Community scenario.

\section{Wildlands}

Nearly all undeveloped land remains as forest. There is a modest expansion of agricultural land area, based on a continuation of 1996-2010 trends. Most forests are managed to support sustainable wood harvest, while a minority of forests are protected from most forms of active management, providing areas where forest succession is shaped by natural processes (Foster et al. 2010).

\section{Food}

Expansion of agricultural land combines with shifting dietary preferences to increase regional food security and improve the diet of New England residents, as described by Donahue et al. (2014). In accordance with health recommendations, consumption of vegetables, fruit, whole grains, and protein-rich plants increases, while consumption of refined grains, meat, dairy, oils, and discretionary calories decreases. Agricultural land area in New England triples by 2060 and the agricultural land area of New Hampshire more than quadruples in order to meet the target of supporting 50\% of New England calories produced within New England.

\section{LITERATURE CITED}

Addison, C., S. Zhang, and B. Coomes. 2013. Smart Growth and Housing Affordability: A Review of Regulatory Mechanisms and Planning Practices. Journal of Planning Literature 28(3):215-257. 
Boutin, Cataldo, Feltes, Fuller Clark, Little, Reagan, Watters, Hunt, and Matthews. 2016. Relative to accessory dwelling unitis. Page SB 146.

Donahue, B., J. Burke, M. Anderson, A. Beal, T. Kelly, M. Lapping, H. Ramer, R. Libby, and L. Berlin. 2014. A New England Food Vision. Page 44. Food Solutions New England.

Ehrenhalt, A. 2012. The Great Inversion and the Future of the American City. First edition. Knopf, New York.

Foster, D., B. M. Donahue, D. B. Kittredge, K. F. Lambert, M. L. Hunter, B. R. Hall, L. C. Irland, R. J. Lilieholm, D. A. Orwig, A. W. D’Amato, E. A. Colburn, J. R. Thompson, J. N. Levitt, A. M. Ellison, W. S. Keeton, J. D. Aber, C. V. Cogbill, C. T. Driscoll, T. J. Fahey, and C. M. Hart. 2010. Wildlands and Woodlands: A Vision for the New England Landscape. Harvard Forest; Harvard University Press, Cambridge, Massachusetts.

Gittell, R., and J. Orcutt. 2012. Science and Technology Plan: Shaping New Hampshire's Economic Future. University of New Hampshire.

Haven, P. 2013. Issue Brief: Federal Funding for U.S. Transit and Roadway Infrastructure. Environmental and Energy Study Institute, Washington, D.C.

Johnson, J. S., and E. Talen. 2008. Affordable housing in new urbanist communities: A survey of developers. Housing Policy Debate 19(4):583--613.

Meyer, S. R., C. S. Cronan, R. J. Lilieholm, M. L. Johnson, and D. R. Foster. 2014. Land conservation in northern New England: Historic trends and alternative conservation futures. Biological Conservation 174:152-160.

New Hampshire Climate Policy Task Force. 2009. The New Hampshire Climate Action Plan: A Plan for New Hampshire's Energy, Environmental and Economic Development Future. Prepared by NH Department of Environmental Services.

NH Office of Energy and Planning. 2014. County Population Projections, 2013 by Age and Sex.

North East Foresters Association. 2013. The Economic Importance of New Hampshire's ForestBased Economy 2013.

Roseen, R., T. V. Janeski, J. J. Houle, M. H. Simpson, and J. Gunderson. 2011. Forging the Link: Linking the Economic Benefits of Low Impact Development with Community Decisions. UNH Stormwater Center.

USDA Forest Service. 2005. Executive Summary of the Final Environmental Impact Statement for the Land and Resource Management Plan: White Mountain National Forest. 